\title{
A gênese da proteção legal para além do monumento no Brasil: o projeto de José Wanderley de Araújo Pinho e seus diálogos com a legislação estrangeira'
}

The genesis of legal protection beyond the monument in Brazil: José Wanderley de Araújo Pinho's project and his dialogues with foreign legislation.

http://dx.doi.org/10.1590/1982-02672019v27e26

\section{RENATA CAMPELLO CABRAL ${ }^{2}$}

https:// orcid.org/0000-000 1-6482-0233

Universidade Federal de Pernambuco/ Recife, PE, Brasil

RESUMO: Somando-se a pesquisas que procuram refletir sobre os antecedentes do Serviço do Patrimônio Histórico e Artístico Nacional (Sphan) e desconstruir narrativas que colocam a figura de Mário de Andrade no centro do mito fundador da instituição, o presente artigo procura mostrar a importância das contribuições do deputado baiano José Wanderley de Araújo Pinho para a introdução da proteção legal no Brasil para além do monumento isolado, a partir da análise de seu Projeto de Lei n² 230 de 1930. Para tanto, intenta-se estabelecer relações entre essa proposição e o Decreto-lei n 25 de 1937, que cria o Sphan, e, sobretudo, identificar, a partir de leituras intertextuais, citações, nessa proposta do deputado, de legislações estrangeiras, como a espanhola e a italiana.

PALAVRAS-CHAVE: Iphan. Patrimônio Urbano. Wanderley Pinho.

1. A presente pesquisa teve seu início quando compus equipe em projeto coordenado pela prof ${ }^{\text {a }}$ Virgínia Pontual. Agradeço a Pontual $\mathrm{o}$ apoio recebido, que se materializou por meio de disponibilização de um bolsista de apoio técnico - Aline Barcelar e, posteriormente, Karine Cortez - a quem agradeço a dedicação. Desenvolvi a pesquisa durante o período de pós-doutoramento no exterior, realizado com apoio da Capes (GPCT/Processo 88887.185214/2018-00). Sou grata, nesse sentido, a essa instituição e a toda a contribuição recebida a distância de Sônia N. de Lima, chefe do arquivo do Instituto Histórico e Geográfico Brasileiro; Maria Isabel Lenzi e Daniella Gomes, do Arquivo Histórico do Museu Histórico Nacional; Simone Santana, bibliotecária da Biblioteca Ruy Barbosa (Instituto Geográfico e Histórico da Bahia); Renan Castro, coordenador do Programa de Arquivos Pessoais do CPDOC-FGV; e da Coordenação de Relacionamento, Pesquisa e Informação do Centro de Documentação e Informação da Câmara dos Deputados. 
2. Docente do Departamento de Arquitetura e Urbanismo (DAU) e do Programa de Pós-Graduação em Desenvolvimento Urbano (MDU) da Universidade Federal de Pernambuco (UFPE). Vice-líder do Laboratório de Urbanismo e Patrimônio (LUP/ MDU). E-mail: <renatacabral@yahoo.com.br>.
ABSTRACT: The present article aims to evaluate the contribution of the congressman José Wanderley de Araújo Pinho to the legal protection of the Brazilian heritage through the analysis of his legislation's proposal $n^{\circ} 230$ from 1930. It builds on other researches that seek to reflect on the background of the constitution of Sphan (The National Historical and Artistic Heritage Service) and to deconstruct historical narratives that place the figure of Mário de Andrade at the center of the founding myth of the institution. We establish relations between Pinho's proposal and the Decree-Law n 25 from 1937, that creats Sphan, and most importantly, we try to identify how the congressman used foreign legislations as reference to his proposal such as the Spanish and Italian's legislations.

KEYWORDS: Iphan. Urban Heritage. Wanderley Pinho. 
Desde a década de 1990, trabalhos como o de Rubino (1991) questionam "o mito de origem" do Iphan e o lugar de "proto-história" dado às iniciativas anteriores à criação do órgão. Nessa perspectiva de revisão, propostas de constituição de uma instituição de proteção nacional anteriores ao anteprojeto de Mário de Andrade (1936), como as de Luiz Cedro (1923), de Jair Lins (1925), de José Wanderley de Araújo Pinho (1930) e até mesmo de figuras "improváveis" ${ }^{3}$ como Oswald de Andrade (1926;1930), ganham relevância. Passam a interessar, também, os processos de constituição e de ałuação dos órgãos de preservação estaduais na Bahia e em Pernambuco, criados antes do serviço federal ${ }^{4}$ assim como da Inspetoria de Monumentos Nacionais do Museu Histórico Nacional (1934-1937). 5 São pesquisas que contribuem para complexificar a história das ideias e práticas de preservação patrimonial no Brasil, adensando redes, contextualizando panos de fundo comuns, identificando processos de continuidade e circulação de ideias.

Para além da ampliação da participação de agentes nacionais, o presente artigo entende ser importante a identificação - nos documentos por meio dos quais se buscava a fundação da proteção do patrimônio nacional - de diálogos com as legislações internacionais.

Marcia Chuva, ${ }^{\circ}$ por um lado, destaca o caráter referencial da legislação francesa, apesar da ausência, segundo ela, da explicitação de vínculos com a legislação internacional nas narrativas de agentes como Lucio Costa. ${ }^{7}$ Por outro lado, lembra que Gustavo Capanema, na "exposição de motivos"8 para encaminhar o texto do decreto-lei ao presidente Vargas, comenta ter sido consultada a legislação internacional para o assunto.

Para a autora,

Apesar do papel decisivo atribuído ao anteprojeto, outros textos também mediaram a produção do decreto lei n 25/1937, tendo Rodrigo Melo Franco de Andrade assumido o papel de articulador de diversas proposições, algumas na forma de projetos de lei, que circularam no Congresso Federal, na década de 1920, além do caráter referencial da legislação francesa, de 1913, que instrumentalizou várias dessas propostas. No entanto, a referência a uma possível influência estrangeira não foi reconhecida por aqueles que viveram de perto aquele momento, ao se contar a história da produção do texto legal, cuja memória histórica tem priorizado a influência de Mário de Andrade nesse processo. ${ }^{9}$
4. Sobre a inspetoria pernambuca, cf. Cantarelli (2016); sobre a inspetoria baiana, cf. Cerávolo (2014) e Dócio (2014). Cantarelli recentemente defendeu tese de doutoramento, abordando outras iniciativas além das inspetorias pernambucana e baiana, a exemplo das primeiras ações do governo federal, como as empreendidas pela Diretoria Geral de Informações, Estatística e Divulgação. Cf. Cantarelli (2019).

5. Cf. Magalhães (2004; 2017).

6. Chuva (2009, p. 152).

7. Chuva (2009, p. 189) identifica essa ausência a partir de entrevista com Costa (1992).

8. Brasil (1980, p. 72-73).

9. Chuva (2009, p. 152). 
10. Ibid., 2009, p. 156.

11. Andrade (1952, p. 55 e 56) apud Andrade (2012, p. 107-108).

12. Cf. Brasil (1936).

13. Cf. Pinho (1930), apud Brasil (1980, p. 46).
Avaliando os projetos de lei dos anos 1920, a autora reafirma a influência francesa. Para ela, um dos aspectos que reunia os projetos de lei de Luiz Cedro, Augusto de Lima Júnior e José Wanderley de Araújo Pinho era

- fato de terem possivelmente se baseado na legislação da França de 1913, aspecto perceptível devido a algumas semelhanças que se evidenciam nos textos. Primeiramente, por proporem a criação de uma "inspetoria", dentro da estrutura ministerial pertinente, e utilizarem a noção de classificação e/ou catalogação de monumentos a serem incluídos numa lista geral, tal e qual a norma francesa. ${ }^{10}$

Ampliando essas pesquisas que realizam leituras intertextuais envolvendo legislações internacionais, nos concentraremos na contribuição do deputado baiano José Wanderley de Araújo Pinho (1890-1967) às ideias em torno da tutela federal para além do monumento isolado, incluindo conjuntos urbanos e o contexto do monumento, a partir de seu projeto de lei de número 230 de 1930.

A proposição de Wanderley Pinho ganha maior relevância por se poder construir o vínculo entre suas sugestões e o Decreto-Lei n 25 de 1937 (daqui por diante $\mathrm{DL} 25 / 37$ ), que organiza a proteção do patrimônio histórico e artístico nacional, como poderá ser visto com mais detalhes à frente. Em publicação de 1952, Rodrigo Melo Franco de Andrade destaca como "subsídios valiosos", para além do trabalho de Mário de Andrade, e "igualmente utilizados" na confecção do DL 25/37 o anteprojeto do jurista Jair Lins, de 1925, o projeto de lei de Wanderley Pinho, de 1930, o novo regulamento do Museu Histórico Nacional (Decreto n² 24.735, de 14 de julho de 1934), o regulamento do Conselho de Fiscalização das Expedições Artísticas e Científicas no Brasil (aprovado pelo Decreto 24.337, de 5 de junho de 1934, art. $3^{\circ}$ ) e a legislação estrangeira, sobretudo a francesa e a mexicana. ${ }^{11}$

Todas essas referências já aparecem, com exceção do regulamento do Conselho de Fiscalização das Expedições Artísticas e Científicas no Brasil, na apresentação que a Comissão de Educação e Cultura da Câmara dos Deputados faz à Comissão de Justiça do Projeto n ${ }^{0} 511$, de 1936. ${ }^{12}$ Como se sabe, esse projeto depois será expedido pela Presidência da República, com modificações, como um decreto-lei, em 1937, na vigência do Estado Novo.

Pinho incorpora, em sua proposta, edificações em conjunto e sítios de "reconhecida e peculiar beleza" (Art. 3, alínea E). ${ }^{13}$ Agrega, ainda, no rol de bens 
passíveis de proteção, "os imóveis sem valor histórico ou artístico, cuja conservação, não alteração ou demolição sejam necessários para desimpedir ou favorecer a perspectiva a um imóvel histórico-artístico catalogado" (Art. 3, alínea D). ${ }^{14}$

Veremos a presença, nesses aspectos específicos da proposta de Pinho, de consultas e incorporações a legislações provenientes não apenas da França, mas sobretudo da Espanha e da Itália.

É importante destacar que a historiografia já situou a inovação e a atualidade das proposições de Pinho, mas não chegou a identificar as referências internacionais que as ancoraram. Sant'Anna, ${ }^{15}$ por exemplo, pontua que é nesse projeto de Pinho que os conjuntos urbanos e sítios surgem pela primeira vez como objetos de preservação em propostas brasileiras. Rubino ${ }^{16}$ comenta que "Nessa classificação detalhada [do que proteger], aparece pela primeira vez a necessidade de demolição de um imóvel que impedisse a visibilidade de um bem privilegiado, noção de entorno que distingue esse texto dos precedentes".

Sant'Annal7 observa que "a questão da ambiência assume nesta proposta de Pinho uma importância e uma abrangência bastante atuais". E entende que sua concepção é "muito avançada para a época". Para ela,

A vizinhança é alçada ao mesmo status legal do bem catalogado, sendo igualmente passível de intervenções para sua conservação ou eliminação, conforme impeça ou favoreça a visibilidade do bem. As ações nesta área devem também ser autorizadas pela Inspetoria de Defesa do Patrimônio Histórico e Artístico Nacional, sendo prevista a possibilidade de desapropriação de imóveis aí situados, sem indenização, se isso for conveniente "à conservação, à luz, perspectiva e moldura de um imóvel catalogado". Segundo essa concepção - muito avançada para a época - o bem protegido é percebido como um quadro, um conjunto em necessária harmonia com o seu entorno. A paisagem que envolve o bem é vista como extremamente importante para a sua apreensão $[\ldots]^{18}$

Trabalho mais recente, de Dócio, também destaca a previsão da possibilidade de conservação do entorno como componente inovador e antecipador:

Pela primeira vez, aparece uma noção mais heterogênea de patrimônio [...] definindo-se os valores arqueológicos, históricos, arquitetônicos e artísticos, prevendo a conservação do entorno e incluindo bens móveis especificados. E, embora com conteúdo diferente, tal ampliação e detalhamento só seriam encontrados na proposta de regulamentação do SPHAN elaborada em 1937.19
14. Ibid.

15. Sant'Anna (1995, p. 91).

16. Rubino (1991, p. 50).

17. Sant'Anna (1995, p. 90).

18. Ibid., 1995 , p. 90

19. Dócio (2014, p. 69). 
21. "Art.19 Nenhuma construção nova se poderá fazer na proximidade de coisa tombada, importando impedir ou reduzir a sua visibilidade, nem se poderá levantar qualquer anteparo, muro ou obstáculo junto à mencionada coisa, nem ahi colocar annuncios ou cartazes de qualquer espécie, salvo autorização expressa do Serviço do Patrimônio Histórico e Artístico Nacional, sob pena de ser mandada destruir a obra ou retirar o objeto, impondo-se, neste último caso, ao responsável a multa de $50 \%$ do valor do mesmo objeto. Fonte: Redacção n 139 1937". Redacção final do projeto n.511, de 1936. Cf. Brasil (1936).

22. A proposição $n^{\circ} 16$, de 1937 , que organiza a proteção do Patrimônio Histórico e Artístico Nacional, originário da Câmara dos Deputados e por ela aprovado, foi, sob o n ${ }^{\circ} 239$, de 1937 , enviado à deliberação do Senado em 13 de abril. $O$ trecho completo do parecer da Comissão de Constituição e Justiça do Senado referente ao artigo 19 é o seguinte: "Há outro dispositivo, o art. 19 , que peca igualmente por inconstitucionalidade. Por esse artigo, 'nenhuma construção nova se poderá fazer nas proximidades da coisa tombada, importando impedir ou reduzir a sua visibilidade; sob pena de ser mandada destruir a obra'. Positivamente, esse dispositivo vai de encontro ao citado art. 113, n. 17. Pois que a construção vedada no art. 19 se tornará inconveniente, o meio de evita-la será a desapropriação por utilidade pública. É verdade que, pelos termos do n. 17 do art. 113, o direito de propriedade é garantido sob a ressalva de não poder ser exercido contra o interesse social. Mas o que devemos enten-
A PROPOSTA DE WANDERLEY PINHO E O DL 25/37

○ início da proteção do entorno no Brasil formaliza-se com o DL 25/37, que estabelece em seu artigo 18:

Sem prévia autorização do Serviço do Patrimônio Histórico e Artístico Nacional, não se poderá, na vizinhança da coisa tombada, fazer construção que lhe impeça ou reduza a visibilidade, nem nela colar anúncios ou cartazes, sob pena de ser mandada destruir a obra ou retirar o objeto, impondo-se nesse caso multa $[\ldots]^{20}$

Na redação original da proposição, o termo usado não era "vizinhança", mas "proximidade". ${ }^{21}$ Durante a tramitação do projeto de lei, a Comissão de Constituição e Justiça do Senado considerou inconstitucional a limitação de construções nas "proximidades" do bem tombado. Segundo parecer dessa comissão, chama-se a atenção para "a servidão" imposta pelo artigo aos proprietários de bens não diretamente tombados e que depreciariam a propriedade:

O direito de propriedade pode sofrer restrições outras, como as determinadas por necessidades de ordem higiênica, ou estética, mas é evidente que, se o Estado não se pode apropriar, sem indenização, das coisas tombadas, que sejam objeto de propriedade particular, muito menos terá o poder de, no interesse delas, condenar os particulares aos prejuízos a que ficarão sujeitos por força do artigo 19 do projeto. Este artigo impõe-thes uma servidão que thes depreciará a propriedade, e tal seja a hipótese, poderá equivaler à perda completa dela. ${ }^{22}$

○termo "vizinhança", proposto em substituição a "proximidade" na reforma do artigo, teria, para Sant'Anna, 23 "o sentido de driblar as arguições de inconstitucionalidade", procurando deixar mais claramente expresso, na redação da lei, que a imposição de restrições ao direito de construir estaria circunscrita "à contiguidade do bem" tombado.

Ttermo usado por Pinho em suas proposições é justamente o de "vizinhança", mas não se sabe se o projeto serviu de referência direta para essa mudança.

A noção de "visibilidade", que estabelece o tipo de relação dessa "vizinhança" com o bem protegido, já estaria na proposição original e não foi modificada na tramitação do projeto. Rodrigo Melo Franco de Andrade menciona 
que o projeto de Wanderley Pinho era vantajoso em relação ao de Jair Lins, por, entre outros motivos, ter "disposições muito mais eficazes e completas" para "resguardar a visibilidade e o destaque dos monumentos, assim como para favorecer-lhes a aparência [...]"24. Pinho utilizava o termo "perspectiva".

$\bigcirc$ projeto de Jair Lins, elaborado por ele na qualidade de relator da comissão designada em julho de 1925 pelo presidente Mello Viana para organizar a proteção do patrimônio histórico e artístico, determina em seu artigo 14 que:

Nenhuma construção nova se poderá fazer a menos de metro e meio do objeto integral ou parcialmente catalogado, salvo autorização especial do Diretor do serviço de tutela ao patrimônio artístico e histórico da União ou dos Estados, sob pena de demolição à custa do infrator e multa do valor a que se refere a letra g do Art. $5^{\circ}$, sempre que da infração resulte qualquer dano ao objeto catalogado. ${ }^{25}$

No esboço de anteprojeto de lei federal, o jurista mineiro cita diversas leis estrangeiras de seu conhecimento, em Áustria, Suécia, Noruega, Grécia, Itália, Dinamarca, Espanha, Egito, Finlândia, Turquia, França, México e Portugal. Todas as leis citadas, com exceção da lei italiana de 1902 e da francesa de 1913, são do século XIX. A lei italiana voltada para as belas-artes já tinha, nesse momento, passado por duas atualizações, em 1909 e 1912, que não são referenciadas pelo jurista.

Analisando as duas legislações mais atualizadas entre as citadas por Jair Lins, a francesa de 1913 e a italiana de 1902, vê-se que apenas a segunda possui artigo que faz alguma referência a distância. A lei italiana sugere que, no caso de novas construções ou elevação de edifícios, as distâncias e normas necessárias deveriam ser prescritas, com vistas a não danificar a "perspectiva" e a "luz" para os referidos monumentos. Teria Jair Lins se espelhado na lei italiana, mas preferido já fixar em norma que distância seria essa? De qualquer forma, um metro e meio seria de fato uma distância pouco eficaz para "resguardar a visibilidade e o destaque dos monumentos, assim como para favorecer-thes a aparência [... $]^{\prime \prime}$, tal como mencionado por Rodrigo M. F. de Andrade. ${ }^{26}$

$\bigcirc$ projeto de Pinho é também mencionado por Andrade como vantajoso em relação ao de Jair Lins por ter um conceito de patrimônio mais "alargado e esclarecido", ${ }^{27}$ sendo citados os artigos $3^{\circ}$ e $4^{\circ}$ da proposta do deputado baiano. No artigo $3^{\circ}$ há referência a edificações em conjunto e sítios de "reconhecida e peculiar beleza". Como se sabe, o DL 25/37 fará, também, menção a sítios, como veremos adiante. der por isso, di-lo o mesmo inciso quando, a seguir, estabelece, como requisito para a legitimidade da desapropriação, a indenização por utilidade ou necessidade pública, no próprio caso em que ela se torne imprescindível por motivo de guerra. O direito de propriedade pode sofrer restricções outras, como as determinadas por necessidades de ordem hygienica, ou esthetica, mas é evidente que, se o Estado não se pode apropriar, sem indemnização, das cousas tombadas, que sejam objeto de propriedade particular muito menos terá o poder de, no interesse dellas, condemnar os particulares aos prejuízos a que ficarão sujeitos por força do artigo 19 do projecto. Este artigo impõe-lhes uma servidão que lhes depreciará a propriedade, e tal seja a hypothese, poderá equivaler à perda completa della." Cf. Brasil (1937a).

23. Sant'Anna (1995, p. 94-5).

24. Andrade (1952, p. 45) apud Andrade (2012, p. 97).

25. Lins (1925), apud Brasil (1980, p. 44).

26. Andrade (1952, p. 45) apud Andrade (2012, p. 97).

27. Ibid. 
28. No IHGB Rio de Janeiro, encontra-se projeto datilografado, não datado, com pequenas diferenças em relação ao aqui transcrito (proveniente de Brasil, 1980). No projeto datilografado: a) Os rochedos e pedras com inscripçoes epigraphicas de valor archeologico ou histórico; b) Os terrenos em que se encontrem cousas de valor archeologico; c) As cimalhas, os frisos, architraves, portas, janelas, columnas. Azulejos, tectos, obras de marcenaria, pinturas muraes e quaesquer ornatos architectonicos ou artísticos que possam ser retirados de uma edificação para outra e que retirados muitilem ou desnaturem, o estylo do imóvel ou a sua unidade, qualquer que seja o material de que se acchem constituidos e ainda quando tal mutilação não prejudique aparentemente $o$ mérito artistico ou historico do imovel a que estavam aderidos; d) Os imóveis sem valor histórico ou artistico, cuja conservação, não alteração ou demolição sejam necessários para desimpedir ou favorecer a perspectiva a um imóvel historico-artistico catalogado; e) As edificaçoes isoladas ou em conjunto, os sitios de reconhecida e peculiar bellesa, cuja proteção e conservação sejam necessarias para manter os aspectos típico - artistico ou pinturesco - de que se revistam.

29. a) Os rochedos, pedras tumulares, e outras aderidas a imóveis com inscrições de valor arqueológico ou histórico; b) Os terrenos em que se encontrem coisas de valor arqueológico ou históricos.

30. Cf. Espanha (1926).

31. Apud Iphan (1980, p. 47).

32. Cf. Jaen (1990); Jiménez (2016).
CONJUNTOS, SÍTIOS, LUZ, PERSPECTIVA E MOLDURA

Será no seu artigo $3^{\circ}$ que o projeto de Pinho define os bens passíveis de ser submetidos ao efeito da lei. ${ }^{28}$ Percebe-se, na proposição, atenção especial para: i) os vestígios arqueológicos; ${ }^{29}$ ii) os chamados, hoje, bens integrados; iii) os edifícios que indiretamente interferem no imóvel catalogado, relacionados a ele pela ideia de "perspectiva"; iv) conjuntos de edificações e sítios considerados como detentores de aspectos "típico-artístico" e "pitoresco".

A definição do que preservar na proposta de Pinho parece fortemente marcada pelo Real Decreto-Ley espanhol de 9 de agosto de 1926 sobre Protección y Conservación de la riqueza artística, conhecido como Ley sobre el Tesoro Artístico Nacional. Encontra-se em seu acervo (IHGB-Rio de Janeiro) exemplar desse decreto ${ }^{30}$ (figura 1).

A alínea E da proposta de Pinho é uma tradução direta da legislação espanhola. Nela, estão definidos como passíveis de proteção "as edificações isoladas ou em conjunto, os sítios de reconhecida e peculiar beleza, cuja proteção e conservação sejam necessárias para manter-lhe o aspecto típico-artístico ou pitoresco de que se revistam". ${ }^{31} \mathrm{Na}$ segunda alínea do artigo $2^{\circ}$ do Real DecretoLey espanhol, que define os imóveis que fazem parte do "tesoro artístico nacional", estão registrados como parte desse tesouro, igualmente:

b) Las edificaciones o conjunto de ellas, sitios, y lugares de reconocida y peculiar belleza, cuya proteccción y conservación sean necesarias para mantener el aspecto típico, artístico y pintoresco característico de España, siempre que así se haya declarado o en lo sucesivo se declare por el Ministerio de Instrucción pública y Bellas Artes.

Apesar da amplitude dos objetos passíveis de preservação presentes na proposta de Pinho, é interessante observar, contudo, que a lei da qual ele faz uso para escrever a alínea $E$, era, nesse aspecto, muito mais completa. Na lei espanhola, esse artigo dialogava com o teor geral da lei, que previa, de forma extremamente inovadora em âmbito internacional ${ }^{32}$ dispositivos de conservação desses conjuntos e sítios. Há, nessa lei, outros artigos que permitem a gestão da conservação articulada ao planejamento urbano. 


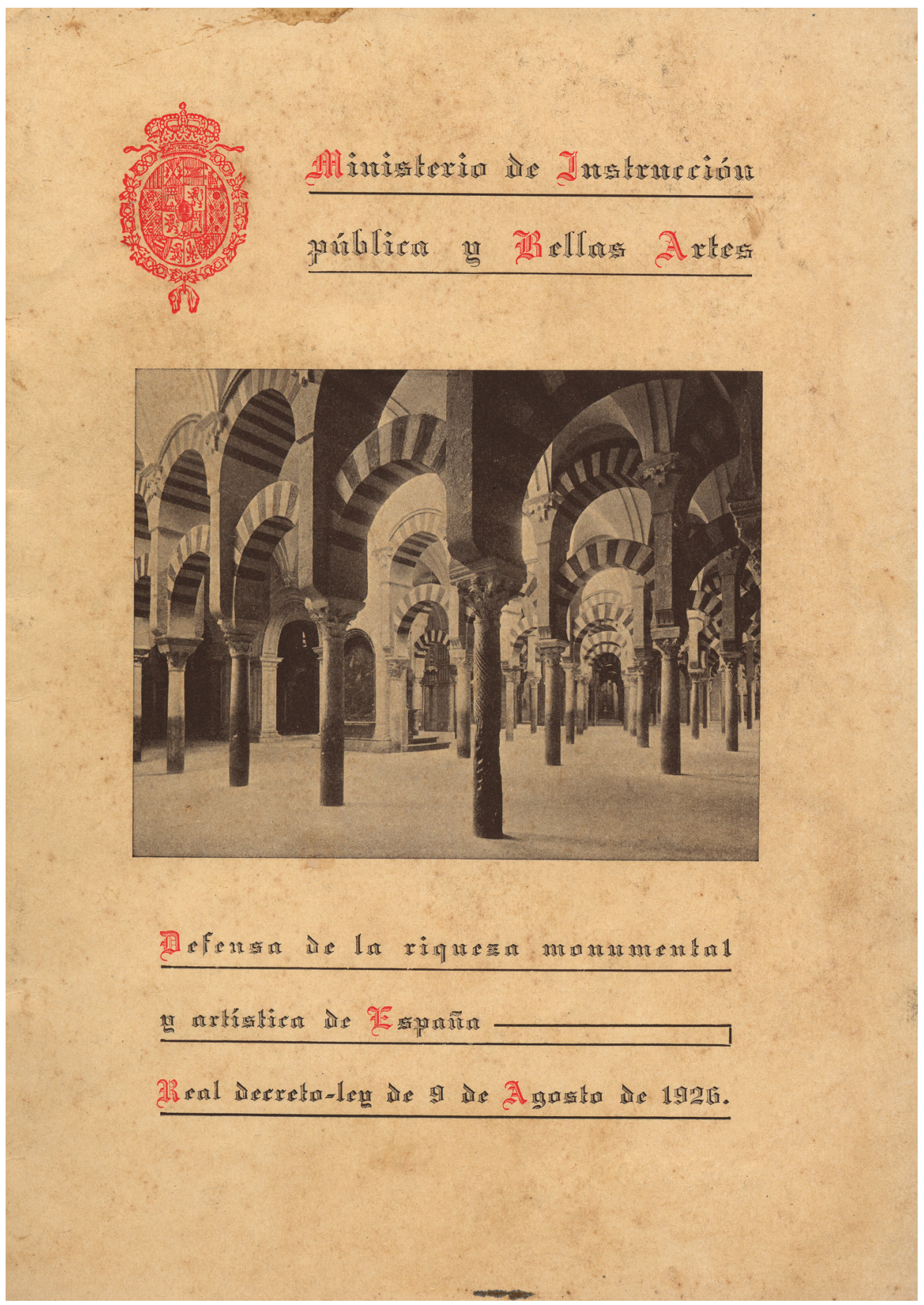

Figura 1 - Exemplar do decreto-lei espanhol de 9 de agosto de 1926, pertencente a Wanderley de Araújo Pinho. Fonte: Fundo Wanderley Pinho, IHGB. 
33. Declaración de utilidad pública. Art. $7^{\circ}$ Se declara de utilidade pública la conservación, protección y custodia de los monumentos arquitectónicos que forman parte del tesoro histórico artístico de la nación, así como la defensa del carácter típico y tradicional de pueblos y ciudades que, por su importancia, lo merezcan. Espanha (1926, p. 10)

34. A quién corresponde la iniciativa para incoar estos expedientes. Art. 20. El Gobierno, a petición de las ciudades y pueblos, por acuerdo tomado em sesiones de pleno del Cabildo Municipal, a instancias de las Comisiones de Monumentos o de la Comisaría Regia del Turismo, en petición dirigida al Ministerio de Instrucción pública y Bellas Artes, o a solicitude de las Reales Academias de San Fernando y de la Historia, podrá acordar la declaración de ciudades y pueblos artísticos que entrarán a formar parte del tesoro nacional. El Ministerio de Instrucción pública y Bellas Artes podrá también adoptar por sí mismo estos acuerdos. Las solicitudes hechas por las ciudades y pueblos em virtude de acuerdo municipal así como las elevadas al Ministerio de Instrucción pública por la Comisión de Monumentos, deberá ser informadas por la Real Academia de San Fernando y de la Historia y remitidas a la Junta de $\mathrm{Pa}$ tronato, que las elevará al Ministerio de Instrucción pública y Bellas Artes para la resolución que proceda. Espanha (1926, p. 19-20).

35. Planos de ciudades incluídas en el tesoro artístico nacional. Art. 21. De las ciudades e pueblos total o parcialmente declarados o que se declaren incluídos en el tesoro artístico nacional, se levantarán por los respectivos ayuntamientos planos
Declara-se de utilidade pública, no artigo $7^{\circ}$, a defesa do "carácter típico y tradicional" de "pueblos y ciudades". ${ }^{33}$ E os artigos 20, 21 e 22 são dedicados aos modos de efetivação dessa proteção ampliada. $\bigcirc$ de número 20 estabelece quem poderá solicitar e decidir pela declaração de vínculo das "ciudades y pueblos", aqui adjetivados como "artísticos". ${ }^{34} \mathrm{O}$ artigo $21^{35}$ prevê a confecção de planos na escala 1:5.000, identificando por meio de círculos as áreas non aedificandis, assim como marcando com cores diversas desde os edifícios de valor artístico ou histórico até os "lugares, calles, plazas y barriadas" pitorescos. Esse mapeamento vincularia esses espaços à lei, restringindo a execução de qualquer obra sem a devida autorização das entidades centrais e provinciais correspondentes. $\bigcirc$ artigo 22, por fim, prevê diretrizes especiais para a conservação dessas cidades. ${ }^{36}$

Caterina Moggian Barban, ${ }^{37}$ em texto sobre a legislação relativa aos setores de salvaguarda na Espanha, observa que, além do conceito de conjunto urbanístico, a lei espanhola coloca as bases para o moderno sistema espanhol de tutela dos tecidos urbanos históricos fundado sobre a forte correlação entre norma de tutela do patrimônio e planejamento urbano. Essas duas aquisições são extremamente importantes e marcam a atualidade e a abertura de interpretação do artigo proposto. ${ }^{38}$

Uma última aquisição importante da legislação espanhola diz respeito à presença explícita da dimensão da "cultura", antecipando aquisições ampliadas internacionalmente com a Carta de Veneza, de 1964. ${ }^{39}$ Como assinala Jiménez, ${ }^{40}$ é importante destacar que

no obstante que a los aspectos históricos y artísticos se suma la noción de cultura, de tal forma que en el Real Decreto-Ley de 9 de agosto de 1926, en su artículo 1, se señala que "constituyen el tesoro artístico nacional el conjunto de bienes muebles e inmuebles dignos de ser conservados para la Nación por razones de Arte y cultura".

Pelo exposto, podemos pensar que a incorporação por Pinho do texto espanhol foi extremamente tímida. Deve, certamente, ter sido uma redução muito calculada diante do que ele entendia serem as necessidades brasileiras e imposições de limitações ao direito de propriedade de então. No parecer que o projeto receberá da Comissão de Constituição e Justiça ainda em 1930, como veremos adiante, o relator Celso Spínola sugere que as restrições ao direito de propriedade previstas pudessem ser atenuadas ou modificadas, assim como as penas previstas. A função social da propriedade será instituída no Brasil apenas pela Constituição de 1934.

O artigo proposto por Pinho ficou isolado do resto da lei, que é, predominantemente, voltada aos bens móveis e integrados. Dos 31 artigos, dez 
são exclusivamente dedicados a esses bens (artigos 9, 15, 16, 17, 18, 19, $26,27,28,291$. Pinho também utilizou a lei espanhola na redação da alínea C do artigo $3^{\circ}$ de sua proposta, referente aos objetos integrados. ${ }^{41}$

É na alínea d) da proposta de Pinho que a proteção do entorno é tratada. Nela, verificam-se referências à legislação francesa e à italiana. Incorporam-se, no rol de bens passíveis de proteção, "os imóveis sem valor histórico ou artístico, cuja conservação, não alteração ou demolição sejam necessários para desimpedir ou favorecer a perspectiva a um imóvel histórico-artístico catalogado". ${ }^{42}$

Essa alínea d) da proposição traz semelhanças com o artigo $1^{\circ}$ da lei francesa de 1913 que inclui, entre os imóveis suscetíveis à classificação, aqueles "dont le classement est necessaire pour isoler, dègager ou assainir um immeuble classé ou proposé pour le classement". Aparece, contudo, na alínea d), a palavra "perspectiva", termo usado na legislação italiana, como será visto adiante.

Outro artigo do projeto de Wanderley Pinho, de número 14, define que

a construção, reconstrução, modificação e destruição de imóveis e alteração de jardins e terrenos na vizinhança de algum imóvel catalogado depende do assentimento da Inspetoria de Defesa do Patrimônio Histórico-Artístico Nacional, ou das repartições congêneres estaduais.

Em seu parágrafo único, anota:

Se isso julgarem conveniente à conservação, à luz, perspectiva e moldura de um imóvel catalogado, poderão a Inspetoria, as repartições congêneres, os poderes estaduais ou municipais, desapropriar os imóveis, jardins, e terrenos da vizinhança de um imóvel catalogado.

Vê-se nesse parágrafo único a menção a três palavras: perspectiva, luz e moldura. A legislação italiana de 1902 e suas atualizações de 1909 e 1912 tinham apenas as palavras "luce" e "prospettiva". Mas a interpretação da palavra perspectiva na ltália vinha gerando disputas jurisprudenciais desde a década de 1910.43 Em conclusão a uma dessas disputas, o magistrado da Corte de Cassação emitiu uma máxima, já em 1920, em que se atribui ao Ministério da Instrução Pública o poder de atuar também no campo da harmonização com o contexto do monumento, a partir da noção de "perspectiva" presente na lei, que não poderia ser lida de forma restritiva, como sinônimo apenas de visada: topográficos a una scala no inferior a I: 5.000, y en ellos se acotarán, por medio de círculos, las superficies sujetas a servidumbre de no edificar libremente, marcándose com distintas tintas los edificios artísticos o históricos, lugares, calles, plazas y barriadas pintorescas, en las cuales no podrá hacerse obra alguna sin la autorización de las entidades central y provinciales correspondientes. De esta superfície se levantarán planos con una escala no menor de I: 200. Probibición de obras de ensanche y reforma em sus recintos. En los proyectos de ensanche, reforma interior o exterior de estas poblaciones, se tendrán en cuenta estas demarcaciones y acotamientos. En ellos no podrán los Ayuntamientos realizar obra alguna ni usar de las faculdades de expropiación que concede el Estatuto municipal vigente, sin previo informe de las entidades que intervinieron de la declaración de ciudades o pueblos pertenecientes al tesoro artístico nacional y decisión del Ministero de Instrucción pública y Bellas Artes. Espanha (1926, p. 20).

36. Preceptos especiales para la conservacións de estas ciudades. Art. 22 Los pueblos y ciudades declarados del Tesoro Artístico Nacional deberán llevar a sus Ordenanzas municipales preceptos obligatorios y especiales de conservación de sus monumentos típicos y en las edificaciones modernas de los elementos y detalles propios y distintivos de la antigüedad, dignos de ser conservados por su originalidad y caráter. Espanha (1926, p. 21).

37. Cf. Barban (2002).

38. Barban (2002, p. 99) diz não acreditar não ter a legislação espanhola sentido a influência das ideias do italiano Gustavo Giovannoni. 
Sobre essas ideias no campo legislativo, cf. Cabral (2013).

39. "Art. $1^{\circ}$ - A noção de monumento histórico compreende a criação arquitetônica isolada, bem como o sítio urbano ou rural que dá testemunho de uma civilização particular, de uma evolução significativa ou de um acontecimento histórico. Estende-se não só às grandes criações, mas também às obras modestas, que tenham adquirido, com o tempo, uma significação cultural.” Brasil (2019 [1964]). Para Kühl (2010, p. 307), "[...] tem-se aqui um 'monumento histórico', que pode ser uma obra arquitetônica ou também um sítio, urbano ou rural, que não tenha necessariamente 'valor' excepcional do ponto de vista formal e documental, mas que tenha adquirido uma significação de cunho cultural, que abarca um leque mais amplo de significados (lembrando a expressão 'portadores de mensagem espiritual do passado' do preâmbulo). Ou seja, pela definição, o interesse pode voltar-se a bens por seus aspectos memoriais e simbólicos".

40. Jiménez (2016, p. 356).

41. Na alínea c, Pinho sugere a inclusão de: "As cimalhas, os frisos, arquitraves, portas, janelas, colunas, e quaisquer ornatos (arquitetônicos ou artísticos) que possam ser retirados de uma para outra e que, retirados, mutilem ou desnaturem o estilo do imóvel ou a sua unidade, qualquer que seja o material de que se acham constituídos e ainda quando tal mutilação não prejudique aparentemente o mérito artístico ou histórico do imóvel a que estavam aderidos". Cf. Pinho (1930) apud Brasil (1980, p. 46). A redação de Pinho traduz parte do artigo $4^{\circ}$ da lei espanhola e é mais didática, incorporando
Nos casos de construções ou reconstruções na proximidade de monumentos, o Ministério da Instrução Pública tem a faculdade de intervir não apenas para prescrever as medidas e as distâncias dos edifícios, mas, além disso, para ditar aquelas normas e aqueles critérios de ordem estilística e artística que valem para harmonizar os próprios edifícios com o ambiente monumental. ${ }^{44}$

Porque teria Pinho inserido a palavra "moldura" em 1930? $\bigcirc$ deputado brasileiro, bacharel em Ciências Jurídicas e Sociais pela Faculdade de Direito da Bahia (1910), conhecia a jurisprudência italiana e sabia dos problemas de interpretação da palavra "perspectiva"? A palavra "moldura" teria sido escolhida por ele para abarcar esse sentido de harmonização dos edifícios como o "ambiente monumental", tal qual sugeria a máxima da corte italiana?

Por um lado, o caso levado à Corte de Cassação, iniciado em Perugia, foi apresentado por Luigi Parpagliolo na coletânea de leis Codice delle antichità e degli oggetti d'arte, mas apenas em 1932. Por outro lado, o periódico italiano II Foro Italiano, facilmente encontrado nas bibliotecas jurídicas italianas, publicava as decisões jurisprudenciais. Na Faculdade de Direito da Universidade de São Paulo encontram-se exemplares dessa revista.

Para além das publicações jurídicas, uma publicação da Editora Calzone de $1918^{45}$ trazia um parecer da Associação Artística dos Cultores de Arquitetura (Aacar) a respeito da polêmica. $\bigcirc$ parecer tinha sido preparado a pedido de Corrado Ricci (1 858-1934), então diretor-geral das Antiguidades e Belas-Artes, ${ }^{46}$ em meio às citações judiciais ao ministério. Foi quando Ricci escreveu ao presidente da Aacar, convidando a instituição a pronunciar um juízo sobre o significado da palavra "perspectiva", presente na lei de tutela.

A associação organiza, então, uma comissão de estudo. $O$ papel de relator é confiado a Giulio Pittarelli, e depois o memorial recebe acréscimo do engenheiro Gustavo Giovannoni. Pittarelli começa a sua relatoria partindo das definições contidas nos dicionários e cita três "principais significados" para a palavra perspectiva. terceiro significado será depois uilizado por Giovannoni para iniciar sua argumentação. Seria o significado de "vistas naturais dos objetos que se apresentam ao olhar [...]": 


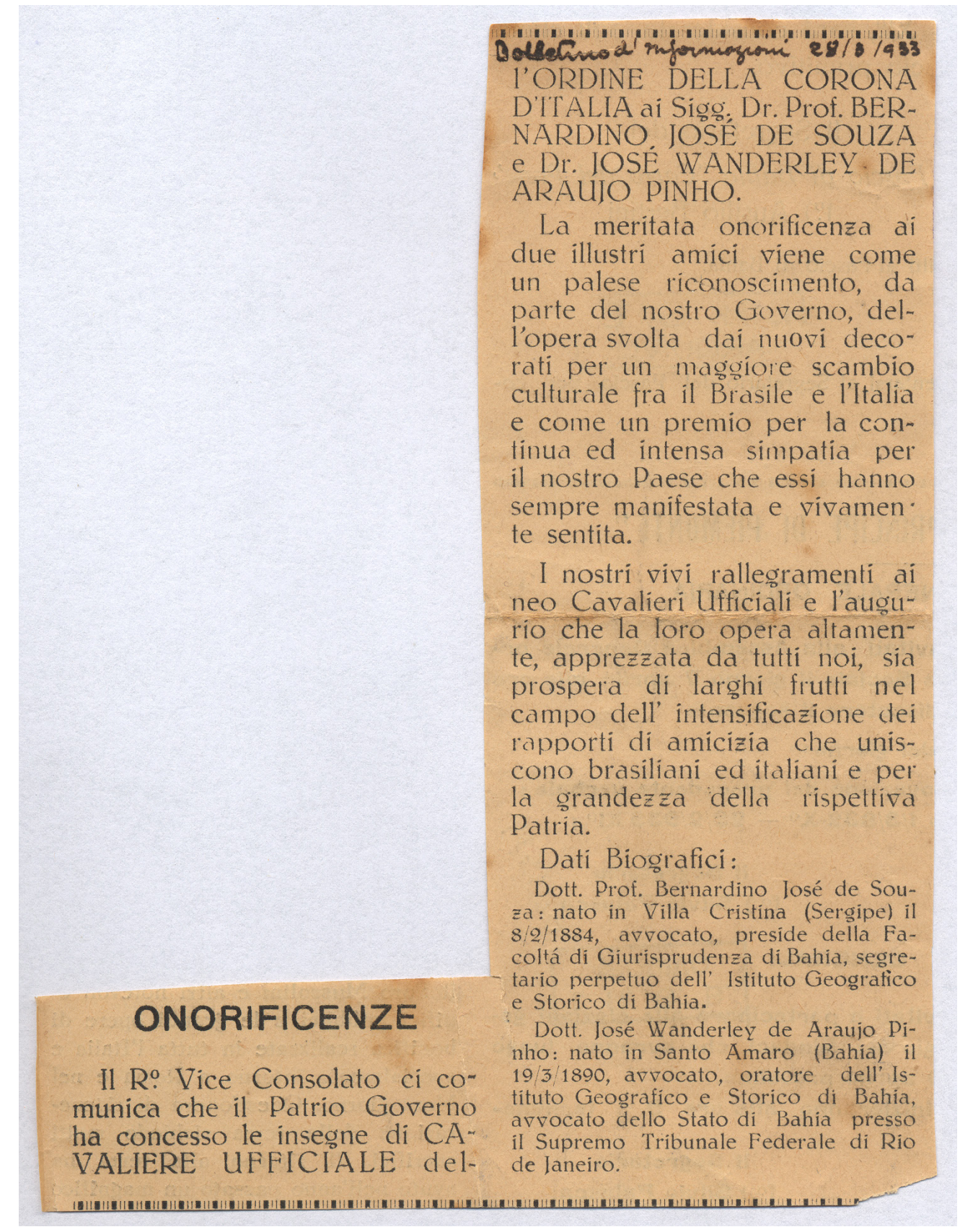

Figura 2 - Recorte classificado à caneta como "bolletino d'informazioni", provavelmente do vice-consulado italiano no Brasil. Fonte: Fundo Wanderley Pinho, IHGB. exemplos dos "elementos" classificados como "consubstanciais" ao edifício, tais como as cimalhas, frisos etc. Na versão original espanhola consta: "Elementos consustanciales a los edificios. Art. $4^{\circ}$ Para los efectos de este decreto-ley, tienen la consideración de bienes inmuebles, además de los enumerados en el art. 334 del Código civil, cuantos elementos puedan considerarse consustanciales con los edifícios y formen parte de los mismos o de su exorno, o lo hayan formado, aunque, en el caso de poder ser separados, constituyan un todo perfecto de fácil aplicación a otras construcciones o a usos distintos del suyo original, culquiera que seja a matéria de que estén formados, y aunque su separación no prejudique visiblemente al mérito histórico-artístico del inmueble a que están aderidos." Espanha (1926, p.9). A respeito da incorporação desses bens, Pinheiro (2011, p. 281) anota que a proposta de Pinho é "a primeira a manifestar consciência de que o bem cultural é um todo indissociável, referindo-se explicitamente à proteção de elementos construtivos [...]".

42. Cf. Pinho (1930) apud Brasil (1980, p. 46).

43. Cf. Cabral (2013) e, também, Pane; Cabral (2014).

44. Cf. Itália (1920).

45. Cf. Giovannoni; Pittarelli (1918).

46. Ricci assume esse cargo em 1906 e permanece nele até 1919. A direção-geral é, na hierarquia institucional, um braço do Ministério da Instrução Pública e tem, articulada a ela, a partir de 1907 , um sistema periférico de superintendências regionais. 
47. Giovannoni; Pittarelli (1918, p. 8).

48. Como informam Consuelo Pondé de Sena (1992) e Maria Teresa Navarro de Britto Matos (2000), o acervo documental de Wanderley Pinho foi dividido entre quatro instituições. Dentre essas, a presente pesquisa restringiu-se ao Instituto Histórico e Geográfico Brasileiro (IHGB), no Rio de Janeiro, que conserva maior parte do fundo, e ao Arquivo Histórico do Museu Histórico Nacional, também no Rio de Janeiro, via consulta ao inventário da Coleção Wanderley Pinho (1.259 folhas). Além deles, as demais instituições são: o Arquivo Municipal de Salvador (com documentos referentes ao período de 1945 a 1949) e o Arquivo Público do Estado da Bahia (Apeb). Em Matos (2000, p. 207-14), encontra-se um inventário/sumário dos documentos do Apeb.

49. Trecho traduzido pela autora, do recorte reproduzido na figura 2 .

50. Cf. perfil de Pinho como sócio falecido do Instituto Histórico e Geográfico Brasileiro em $<$ https://bit.ly/35X9X8N>.
[... nos parece então fora de dúvida que esse deva responder ao terceiro dentre os significados indicados, e que, então, equivalha, mais precisamente, à cena que fecha o monumento, ao quadro entre o qual esse é composto, ao ambiente (para dizer em uma palavra) do monumento mesmo, quando as massas arquitetônicas e as linhas naturais, as condições de forma, de cor, de caráter artístico desse ambiente tenham, na maneira de vê-lo, de apreciá-lo, de entender o seu valor, uma direta função de arte. ${ }^{47}$

Vê-se que, na interpretação da Aacar, particularmente a partir das contribuições de Giovannoni e Pittarelli, a noção de "perspectiva" poderia tentar ser explicada com palavras como "cena", "quadro" e "ambiente". A palavra "moldura", escolhida por Pinho, não parece fugir aos sentidos escolhidos pela associação para dar maior largueza ao entendimento de "perspectiva", naquele momento interpretado como "visual" pela parte contrária ao ministério.

Os italianos, na revisão da lei em 1939 incorporarão, para evitar tal tipo de polêmica envolvendo a palavra "perspectiva", uma palavra adicional - "ambiente" -, deixando à velha palavra "prospettiva" menos responsabilidade em tanto significar.

Através de consulta ao catálogo do fundo "Wanderley Pinho" do Instituto Histórico e Geográfico Brasileiro (IHGB), foi identificada a existência de seu projeto de lei datilografado, contudo sem uma apresentação ou justificativa que indique legislações consultadas. ${ }^{48}$ Há um recorte de publicação nomeada à caneta como Bolletino d'Informazioni (figura 2), provavelmente do vice-consulado italiano no Brasil, de 1933, sobre a concessão do título de Cavaleiro Oficial da Ordem da Coroa da ltália a Bernardino José de Sousa e a José Wanderley de Araújo Pinho, em reconhecimento da "obra desenvolvida pelos novos condecorados para uma maior troca cultural entre Brasil e ltália e como um prêmio pela contínua e intensa simpatia pelo nosso País que esses sempre manifestaram e vivamente sentiram" ${ }^{49}$

No mesmo fundo, foram identificados álbuns de fotografias de Wanderley Pinho e sua esposa Estela Calmon de Wanderley, em várias cidades italianas, nos anos de 1928 e 1929. Teria Pinho aproveitado a viagem para se atualizar sobre as questões jurisprudenciais envolvendo a atuação das leis italianas? Sabe-se que em 1928 ele participou da Conferência Interparlamentar de Paris, representando o Congresso Nacional, em contato com delegações estrangeiras. ${ }^{50}$ 


\section{DE BENS MÓVEIS E INTEGRADOS AO ENTORNO DOS MONUMENTOS E EDIFICAÇÕES EM CONJUNTO}

Antes mesmo de se tornar deputado federal pela primeira vez, em 1924, José Wanderley de Araújo Pinho já refletia e procurava atuar em prol da proteção patrimonial no seu estado natal.

Em sessão ordinária do Instituto Geográfico e Histórico da Bahia (IGHB), em julho de 1917, Pinho apresenta proposta para a constituição de uma Comissão dos Monumentos e das Artes no âmbito do IGHB. ${ }^{51}$

Esta teria sido a primeira proposta de criação de um órgão dedicado à proteção do patrimônio material na Bahia, tendo como agente promotor da tutela não o governo, mas o próprio Instituto. ${ }^{52} \bigcirc \mathrm{IGHB}$, criado como entidade vinculada ideologicamente ao regime republicano, imbuiu-se da tarefa de ter protagonismo como guardiã e promotora da história pátria. ${ }^{53}$

O IGHB privilegiou, na constituição de seu corpo, um perfil de intelectual, ou, ao menos, de homem letrado. ${ }^{54}$ Pinho enquadrava-se, segundo Silva, ${ }^{55}$ dentre os intelectuais, particularmente aqueles que poderiam ser classificados como mais "envolvidos" com a entidade, definidos como aqueles que

Tinham seus campos de interesse e de ałuação diretamente relacionados ao Instituto e com ele se identificavam (e foram identificados) inquestionavelmente, participando sempre das instâncias de organização e gestão do Instituto. Foram eles nomes de grande notoriedade nos meios acadêmicos da época (alguns ainda na atualidade), destacando-se quer no Instituto, quer na vida pública por sua atuação profissional ou pela qualidade de seu trabalho intelectual. Podem ser citados como ícones desse grupo, particularmente por sua contribuição à história da Bahia, as figuras de Braz do Amaral, Theodoro Sampaio e Wanderley Pinho, entre outros $[\ldots]^{56}$

pronunciamento de Wanderley Pinho, depois publicado pela revista do instituto, mostra um homem muito sensível ao "sopro iconoclasta das reformas; à triste mania das restaurações" e à "doença das remodelações". Nesse momento, Salvador tinha vivenciado um significativo "sopro" destruidor na gestão de José Joaquim Seabra no governo do estado, entre 1912 e 1916. Seabra empreendeu ações de reforma aos moldes daquelas do Rio de Janeiro na gestão de Pereira Passos (1902-1906), com alargamento de ruas, abertura de avenidas e construção de novos edifícios. ${ }^{57}$
51. Ceravolo (2014, p. 128) contextualiza que entre 1916 e 1918 “já corria a ideia de criação de um museu por parte do governo do Estado da Bahia, para abrigar as relíquias ou troféus concernentes ao patrimônio histórico regional e do Brasil". Ainda segundo ela, haveria "certa sincronia entre o discurso de W. Pinho no IGHB e a criação do museu oficial, indicando, além da proximidade do instituto com a instância política, um movimento em direção à salvaguarda patrimonial".

52. Dócio (2014, p. 40).

53. Silva (2006, p. 103).

54. Ibid., 2006, p. 118.

55. Ibid., 2006, p. 119.

56. Ibid., 2006, p. 119.

57. Cf. estudo sobre o período da primeira gestão de J. J. Seabra em Leite (1996). 
58. Pinho (1918, p. 191).

59. Ibid., 1918, p. 195.

60. Ibid., 1918, p. 195

61. Ibid., 1918, p. 192.

62. As expressões "bens móveis" e "bens integrados" são bastante conhecidos pelo menos desde a criação do Inventário Nacional de Bens Móveis e Integrados do Iphan na década de 1980. O que se convencionou denominar "bens móveis" são "os objetos de arte ou de ofícios tradicionais, ou simplesmente utensílios domésticos ou religiosos que, como o nome diz, podem ser retirados e transportados com facilidade por não estar fixados ou fazer parte indivisível do imóvel tombado". Os "bens integrados" seriam "tudo que fixado na arquitetura integre o monumento, sem que possa ser retirado sem dano ao imóvel ou criando lacuna. Dessa categoria participa toda a decoração interna de casas, fortes, palácios, museus, igrejas e conventos." Cf. <https:// bit.ly/2W82TBy>. Acesso em: 3 jan. 2019.
Pinho registra a construção, por parte de seus contemporâneos, de sentidos pejorativos à palavra "colonial", como o de "qualitativo de ruindade", ou às palavras "antigo e velho", que pareciam a esses mesmos olhos equivaler a "mav e destrutível". 58

Alerta para o perigo do "cosmopolitismo", "desastre a que vamos nos encaminhando nesta trilha de obrigado progresso à outrance", ${ }^{59}$ e defende a conservação das tradições como único caminho de salvação.

Ele vislumbra o risco de uma homogeneidade das culturas nacionais e situa a história e a arte como elementos de resistência contra esse risco:

\begin{abstract}
A facilidade das comunicações, os progressos da navegação, a disseminação da gravura, da fotografia, da imprensa, vão rapidamente tornando a mesma, una e monótona, a face da terra; igualando trajos, nivelando costumes, identificando hábitos, assemelhando instituições. O prazer das viagens dentro de um, de dois séculos, ter-se-á talvez acabado e o touriste caminhará só para ver e contemplar os quadros naturais da paisagem, eternamente variantes no eterno e infinito inventivo poder da paleta do sol e do buril da terra. Mas, ainda assim, há um certo número de caracteres que cada povo se obstina em conservar; e esses são os que promanam da sua história e os que se geram de sua arte. ${ }^{60}$
\end{abstract}

A Bahia é vista por esse sócio do instituto como lugar possível de guarda da tradição e do passado. Ao falar de seu estado nessa perspectiva, percebe-se a visão abrangente de Pinho, que menciona lendas, costumes, monumentos, casas, objetos de arte. Refere certa atmosfera de passado que remete a épocas findas. Para ele,

A Bahia é, e há de ser, felizmente por muito tempo, a região tradicional brasileira: onde as lendas e costumes de antanho conservam a sua poesia melancholica no contraste de um progresso que penetra lentamente; onde como a atmosfera que se respira é um ar do passado cheirando à santidade ingênua de épocas findas; onde o próprio aspecto das cousas e o regimem dos homens são como um viver dos séculos atrás arremedando hábitos novos.

E a razão desse aspecto genuinamente brasileiro que conservamos está nos vestígios que nos restam da grande vida já vivida: nos monumentos, nos templos, nas casas antigas, nas velhas tradições, nos objetos e coisas da arte de outrora. ${ }^{61}$

Apesar dessa gama de vestígios que incluem casas antigas e velhas tradições, Pinho dedica grande parte dos parágrafos seguintes ao tema das destruições dos bens móveis e dos bens integrados. ${ }^{62}$

Ele aponta dois tipos de agentes cujas ações seriam prejudiciais à proteção desses bens. De um lado, estariam os negociantes de antiquarias e os colecionadores, espécies de aves de arribação, imigradas de fora, "afiando as garras" para levar 
para o estrangeiro "por preços de pechincha" móveis, faianças, azulejos, pratas e pinturas. ${ }^{63}$ De outro lado estaria um tipo ainda mais problemático: "os que destroem consumindo e dão ao nada, à poeira e à ruina o que fora sinal de grandeza e opulência". ${ }^{64}$ Seria o caso das destruições de edificações sem proteção de suas relíquias. Interpretando os edifícios como depositórios de elementos artísticos integrados, como tetos, talhas douradas e azulejos, lamenta que a "destruição necessária do que travanca" não esteja sendo acompanhada da salvaguarda desses elementos, nem do registro dos edifícios por meio de fotografias e descrições.

Pinheiro ${ }^{65}$ destaca como a questão da venda dos objetos artísticos brasileiros a estrangeiros é a grande questão mobilizadora da opinião pública nos anos 1920, em detrimento dos cuidados com os exemplares arquitetônicos. Dócio entende que "a noção de preservação expressa por Wanderley Pinho ainda não abarcava a conservação da edificação. Apenas previa o registro das suas características arquitetônicas por meio de fotografias e descrição [...]". ${ }^{\prime 6}$ Contudo é importante observar o teor da crítica de Pinho a algumas reformas por ele exemplificadas e as tipologias de bens previstas por ele em sua proposta.

Ele denuncia reformas que substituem elementos como pintura de tetos, azulejos e remodelam fachadas, interferindo na proteção da unidade estilística e autenticidade do edifício. Em suas palavras, no caso das obras previstas para a lgreja Matriz de Santo Amaro, uma reforma de fachada "num estilo ogival de arremedo, num gótico de fundilhos remendados!"67 Falando de um Palácio também em Santo Amaro, Pinho classifica essas "remodelações" de fachada como "sistema de enfeitar com lambrequins e frisos sem arte nem escola as paredes dos edifícios para thes tirar toda a fisionomia do estilo, todo o colorido de sua idade, todos os motivos do respeito que nos infundem". ${ }^{68}$ Como farão alguns de seus contemporâneos, a exemplo de Gilberto Freyre, no Recife, a substituição da feição colonial pela eclética será condenada.

A proposta de Pinho aos seus colegas da futura Comissão dos Monumentos e das Artes seria: 1. Apresentar relatório anual de seus trabalhos e organizar um programa de ação; 2. Apresentar catálogo do patrimônio histórico-artístico da Bahia.

No seu pronunciamento, ele não adentrará o possível "programa de ações" da comissão, mas apenas fará referência ao catálogo ou inventário. No pouco que diz a respeito desse inventário, não entram os sítios, conjuntos e vizinhança de monumentos, como aparecerá em 1930, nem os costumes, lendas e casas que aparecem no próprio pronunciamento de 1917, mas incorporam-se mais do que os bens móveis. Os bens integrados estão presentes, como os retábulos e entalhaduras, assim como os monumentos e edifícios públicos, os templos e edifícios religiosos. $\mathrm{Na}$ exemplificação de Pinho constam: "monumentos e edifícios públicos; templos e
63. Pinho (1918, p. 192).

64. Ibid., 1918, p. 193).

65. Pinheiro (2011, p. 24950).

66. Dócio (2014, p. 40).

67. Pinho (1918, p. 194).

68. Ibid., 1918, p. 193). 
69. Ibid., 1918, p. 196).

70. Ibid., 1918, p. 195). Ceravolo (2014) já identificara a primeira citação como sendo de Ortigão. Segundo Alice Nogueira Alves (2009, p. 112), O Culto da Arte em Portugal teve sua primeira edição em 1896 e, quatro anos depois, uma edição brasileira.

71. Freyre (2016 [21 set. 1924]).

72. Ortigão (1896, p. 79). edifícios religiosos; alfaias, retábulos, entalhaduras, esculpturas religiosas ou profanas; jóias, faianças, porcelanas, baixelas, mobiliário de todos os estylos; coleções particulares de tudo o que tiver algum mérito artístico ou algum valor histórico". ${ }^{99}$

E qual seria o sentido maior dessa proposta? Constituir-se parte de um "exército da salvação" faria sentido, para ele, na perspectiva do guardar, conservar, orientar e ensinar. Defende que os monumentos nacionais poderiam ser gatilhos ou "instrumento" de desenvolvimento de um "instincto do passado". O português Ramalho Ortigão e sua obra $\bigcirc$ Culto da Arte em Portugal, citados duas vezes no artigo, iluminam essa dimensão. Na primeira citação a Ortigão, Pinho traz a ideia de que o monumento artístico "traduz" a "ação intelectual e política da sociedade que o concebeu" ${ }^{70}$

Ramalho Ortigão em $\bigcirc$ Culto da Arte em Portugal também será utilizado por outro intelectual brasileiro na valorização da tradição e denúncia da homogeneização via estrangeirismos. Em artigo de 1924, Gilberto Freyre, partindo para a ideia de que não seria mau que se agitasse no Recife um movimento a favor dos nomes primitivos das ruas, em constante mudança, lança mão da referência a $\bigcirc$ Culto da Arte em Portugal:

Ramalho Ortigão disse à cidade de Évora o que se pode dizer ao Recife e a Olinda: que ao estrangeiro inteligente não atraem as avenidas novas nem as praças novas. Atraem-no as igrejas antigas, os velhos prédios, as ruas sinuosas e os seus nomes arcaicos ou sugestivos. ${ }^{71}$

A entrada de Ortigão (1836-1915) permite que Freyre fuja ao tema exclusivo dos nomes de ruas indo à cidade, sua arquitetura civil e religiosa e, sobretudo, ao tema das perdas causadas pelas reformas. Nesse breve parêntese, fala dos "restos deliciosos de arquitetura amouriscada" do bairro de São José e das janelas desse lugar, nas casas e nas igrejas. São janelas por ele humanizadas, ganhando olhos a simbolizar testemunhas oculares que se queixam de tantas perdas investidas pelos "reformadores".

Em O Culto da Arte em Portugal, Ortigão, ao falar de Évora, coloca as preexistências como superiores às marcas do presente. Refere-se também aos nomes das ruas e às artes aplicadas. Menciona, por fim, a cozinha tradicional. Denuncia, ainda, o gosto por um pitoresco de falsas ruínas, criado em detrimento da preservação do passado autêntico. Numa narrativa que passeia por diversas cidades a denunciar as perdas de tradições portuguesas e as valorizar, Ortigão chega a Évora dizendo: "Pobre cidade de Évora, um dos nossos mais vastos e mais preciosos museus de arqueologia e d'arte, preferindo como Santarém ser uma estúpida coleção de praças largas e de ruas novas! [...]" ${ }^{72}$ Esse trecho é usado por Freyre em outro artigo, intitulado 
"O Recife e as Árvores". Nele, o autor pernambucano problematiza um tipo de reformismo desejoso de europeização e, sobretudo, de americanização. Um reformismo que destruiria as raízes culturais e faria a gente do local se sentir estrangeira. ${ }^{73}$

contexto de escrita de Ortigão também é motivado pela recusa ao estrangeirismo que incomoda Pinho e Freyre. Como bem situa Malpique:

O Culto da Arte em Portugal, escrito pelo desempenado Ramalho Ortigão, corresponde a uma época em que Ramalho estava ensinando os portugueses a amar a sua própria terra, curando-se dos exageros de louvar o estrangeiro, só porque é o estrangeiro, e denegrindo o que é nacional, só porque é nacional. No próprio Ramalho, esse livro corresponde a uma fase de relativa penitência - a de muito ter olhado para o mundo de fora, com menosprezo no próprio. ${ }^{74}$

Pinho encerra sua fala no IGHB em 1917 com citação de seis parágrafos de C Culto da Arte em Portugal. Nesse trecho, é dada ênfase à ideia que dá nome ao livro de Ortigão: a importância do culto à arte. Nele, conectam-se as noções de arte, religião, tradição, existencialismo e, sobretudo, o nacionalismo que fará Pinho pensar na Bahia como "região tradicional brasileira" e defender o que é característico de cada "povo", como já citado acima. No trecho parafraseado de Ortigão afirma-se que:

É pelo culto da arte ... que a religião da nacionalidade se exterioriza e se exerce.

Desde que nas consciências se extinguiu a fé, é por meio da arte que as tradições se transmitem, que os sentimentos se coordenam, que os afetos se depuram, que as paixões se enobrecem. É pela arte, que as exprime, que a poesia do cristianismo sobreviverá aos seus dogmas no eternecimento, no amor, na saudade dos homens. É também pela arte que em nossa memória a poesia da história sobreleva das instituições, dos sistemas, das teorias e dos homens, sobre que ela versa.

É unicamente pela arte, inerente à natureza humana, progressiva e eterna, que hoje em dia os homens se associam no destino e na solidariedade da espécie.

É pela arte que o gênio de cada raça se patenteia, que a autonomia nacional de cada povo se revela na sua autonomia e se afirma, não só pela sua especial compreensão da natureza, da vida e do universo, mas pelo trabalho coletivo da comunidade, na literatura, na arquitetura, na música, na pintura, na indústria e no comércio.

É pelo culto da arte e pela educação artística que esse culto se compreende, que a produção industrial se especializa, se valoriza pela originalidade característica do produto e transforma pela prosperidade, unicamente determinada pelo ensino, toda a economia de sua nação, como se envidenciou nos últimos tempos em Inglaterra, na Áustria, na Alemanha, por via da simples reconstituição dos museus e da multiplicação das escolas.
73. Conferência pronunciada por Gilberto Freyre em 11 de novembro de 1924, no Colégio Salesiano do Recife e publicada no Diário de Pernambuco, no dia seguinte. Freyre (2016 [12 nov. 1924]).

74. Malpique (1957, p. 182 ) apud Alves (2009, p. 111). 
75. Pinho (1918, p. 198).

76. Ceravolo (2014, p. 129).

77. Pinho (1925, p. 81).

78. Ibid.

79. Peres (1999, p. 97).

80. A previsão de demolição do templo existia desde 1912, com os planos de melhoramentos do governo J. J. Seabra. Peres (1999, p. 48-49) relata os termos de negociação do Instituto com o governo nesse período, que incluía a publicação da revista no Diário Oficial do Estado.

81. Peres (1999, p. 110) afirma que "É através da imprensa diária e de um número especial da Revista, em 1928 , que veremos os intelectuais da Casa da Bahia [IGHB] desfiando seus argumentos favoráveis à preservação da igreja da Sé; Pirajá da Silva, Filinto Bastos, Bernardino de Souza, Teodoro Sampaio, Gama Abreu, Borges de Barros, Pedro Calmon, dentre muitos outros, são aqueles que mais se destacam dentro da campanha para salvação do templo".

82. Pinho (1925, p. 82).
Finalmente, se para cada povo a arte é a segurança da tradição, o refúgio das consciências, o mais puro reflexo da imagem benigna da pátria, a fonte mais caudal de todos os progressos morais, econômicos e até políticos - para cada homem, na tortura de tantas incertezas, na mágua e na ruína de tantas crenças extinctas, de tantos ideias desfeitos no melancólico decurso de nossa idade a arte é ainda - como diz Schopenhauer - "a única flor da vida". ${ }^{75}$

O fechamento da fala de Pinho com trecho poético e emotivo, a conectar a arte a questões sociais e existenciais, mostra sua força retórica. Nesse sentido, Ceravolo bem situa os recursos narrativos de Pinho e resume sua intervenção. Para ela,

[...] $\bigcirc$ tom do discurso de W. Pinho dirigido aos confrades, tornando-os cúmplices pelo estratégico emprego do plural - um "nós", os chamava ao combate e à luta para reagir, esclarecer, pedir, adquirir, protestar e formar um exército da salvação sugerindo uma missão a ser cumprida.

Ainda na sutil trama do discurso, ele recorre a palavras com forte apelo emotivo, suscitando imagens negativas e desastrosas ao relacionar o risco de destruição do passado bem como do antigo e das tradições ao abandono, ao desprezo, a reformas e remodelações, às substituições, às heresias artísticas e ao desamor. $O$ novo, a exemplo do que começava a se esboçar na arquitetura, ao gosto duvidoso. Em contrapartida, os cuidados com a conservação dos bens patrimoniais significavam ensino e orientação para incutir no povo o "instincto do passado"; um passado glorioso a ser venerado para despertar a "alma da nação" antes mesmo de aprender o alfabeto. Era preciso infundir o patriotismo, o civismo, o genuíno brasileiro encravado nos vestígios [...] carregados de aura e esplendor que encontravam na Bahia, região tradicional brasileira, um nicho a ser preservado. ${ }^{76}$

Oito anos depois da fala de Wanderley Pinho no IGHB, em sessão de 22 de março de 1925 nesse mesmo instituto, ele sugere a criação de uma comissão para marcar a posição do IGHB no caso que ele considera já "inevitável" da demolição da Sé de Salvador:"77 "silêncio nosso se não justifica", ${ }^{78}$ diz incisivamente Pinho. Seu lugar de fala parte de dentro do instituto num momento em que este se encontra com grande prestígio social e maior autonomia em relação aos apoios governamentais, como apontado por Peres, ${ }^{79}$ diferentemente do que acontecia no começo da década de 1910, quando o instituto não se posicionou contra a demolição da Sé, mostrando-se mais preocupado com os bens móveis existentes em seu interior. ${ }^{80}$

Pinho parece ser o primeiro a movimentar uma campanha que encontrará mais força a partir de 1928, quando, inclusive, o instituto publicará um número especial dedicado à Sé. ${ }^{81}$

Em sua fala, ele pondera os "motivos de tráfego" 82 defendidos na proposta de reforma urbana, relativizando a necessidade das obras propostas. Em alternativa, 
sugere o alargamento da Ladeira da Montanha, que liga a cidade baixa e a alta, com obras de embelezamento da muralha de sustentação da via, destacando a ideia de uma avenida em terraço para gozo do "incomparável panorama da Bahia". ${ }^{83}$

Sem formação em arquitetura ou urbanismo, Pinho elabora uma fala que se aproxima de ideias, por exemplo, de italianos como Gustavo Giovannoni, publicadas em 1913, de preservar a cidade existente, deixando a nova cidade se desenvolver ao lado da "velha". Enxerga, nos conjuntos urbanos do passado, particularmente os coloniais, valores para além daqueles de monumentos isolados. Em suas palavras:
83. Ibid., 1925, p. 82

84. Ibid., 1925, p. 82-83.

85. A comissão foi formada por Padre Christiano Muller (relator), Theodoro Sampaio e Filinto Bastos. Ibid., 1925, p. 91.

86. Ibid., 1925 , p. 90
Não sei se o digo com senso mas assim o entendo - A nossa cidade tem como um valor grande esse cunho seu característico, que são os aspectos coloniaes de algumas de suas ruas e construções. Toda a orientação de reforma, pois, deveria tomar como diretriz a conservação e resguardo dessas ruas estreitas, tortuosas, inclinadas, mas cheias de casas e palácios de antanho, repletos de arte velha e de tradições antigas. $O$ bairro da Sé, nesse particular, desde a rua da Assembléia à Baixa dos Sapateiros é valiosíssimo, ao touriste, inteligente e a quem não banalisou ainda o espírito nas impressões da mesmice do modernismo.

Respeitemos pois essa velharia que não poderíamos remodelar sem feiura e que só poderemos embelezar destruindo, para levantar sobre as ruínas cousa totalmente nova. Repartamos a cidade velha urbs intangível e a cidade mais nova, sujeita às transformações constantes, estendendo a cidade por toda essa área entre a Barra e ltapagipe, até Amaralina e pelos aterros do cais do Porto. Ofereçamos assim ao visitante e às gerações por vir um museu de antiguidade como um orgulhoso pergaminho de nossa prosápia, no bairro da Sé, e, como um atestado de nossa cultura contemporânea, a nova cidade. Elevemo-nos com esse estalão de alto valor moral na estétia do aproveitar a natureza e no respeito à arte e às lembranças do passado. ${ }^{84}$

A referência a um tipo de turista particular, o "inteligente", dialoga com o debate acima brevemente recordado de Ramalho Ortigão para com Évora e de Gilberto Freyre para com o Recife.

$\bigcirc$ parecer da comissão, emitido apenas seis dias depois, ${ }^{85}$ posicionandose contra a demolição, mostra a distância entre o entendimento mais amplo de Pinho, que mistura conservação e planejamento, com uma visão mais centrada no bem e nos seus valores históricos. A comissão considera o templo em sua configuração atual "sem maior estética" 86 e realiza um elenco de fatos memoráveis nele abrigados, como a realização do Synodo Diocesano, o batismo de ilustres intelectuais, as celebrações de triunfos como o dos brasileiros sobre os holandeses, os personagens da história ali enterrados e as posses ali realizadas.

Percebe-se o caráter fortemente conservacionista da fala de Pinho perante conjuntos urbanos, também, ao comparar suas ideias com as de Jayme Cunha da Gama Abreu, engenheiro civil pela Escola Politécnica do Rio de Janeiro e professor da 
87. Abreu lança perguntas ao leitor: "a Sé ficando onde está atravanca a cidade? Que pretendem d'este trecho da nossa urbs? A conservação das ruas coloniais sem feição alguma, entretanto, característica? Se assim for, antes das Ruas conserve-se a Sé, a qual lhes dará o cunho que, sem ela, lhes faltará indiscutivelmente. Querem fazer d'ele um bairro moderno? O ponto central, o bairro administrativo? Muito bem. Mas para tal feição nova é condição o desaparecimento do venerando templo? Eu digo que não." Ao final do artigo, argumenta "e a higiene? Basta o parecer do eminente Dr. Theodoro Sampaio para que se julgue do que é necessário ao casario limoso e infecto que forma as vielas do vetusto bairro: Picareta n'ele. Salvem-se poucas ruas, umas duas, talvez, nas imediações do convento de S. Francisco, das quais o cunho colonial será mantido, servindo ainda assim à higiene como vielas sanitárias." Cf. Abreu (1928).

88. Dócio (2014, p.60).

89. Peres (1999, p. 164).

90. Cerávolo (2011, p. 200).

91. Cf. Bahia (1927).

92. Cerávolo (2011, p. 198).

93. Ibid., 2011, p. 196.

94. Cf. decreto reproduzido em Peres (1999, p. 233).

95. Ibid
Escola Politécnica da Bahia na cadeira de Arquitetura e Higiene dos Edifícios e Saneamento das Cidades. Abreu defende a conservação da Sé, mas não demonstra nenhum interesse no conjunto edificado do bairro. Propõe um plano alternativo ao da demolição do templo que altera ainda mais as quadras do seu entorno. ${ }^{87}$

Quando a Inspetoria Estadual de Monumentos Nacionais foi criada na Bahia, em 1927, por iniciativa do deputado Pedro Calmon, previu-se legalmente pela primeira vez em nível estadual a noção de entorno, como apontado por Dócio. ${ }^{88}$ A iniciativa de Pedro Calmon ocorreu na gestão de Francisco Marques de Góes Calmon (1924-1928) no governo do Estado. Peres supõe que "o Governador foi influenciado pelo núcleo atuante do Instituto Geográfico e Histórico da Bahia e especialmente por seu genro Wanderley Pinho". ${ }^{89} \bigcirc$ governador era sócio efetivo e fundador do IGHB. ${ }^{90}$

No Fundo Wanderley Pinho do Instituło Histórico e Geográfico Brasileiro, encontra-se uma cópia do regulamento (figura 3). A lápis, há uma dedicatória a Pinho com assinatura de "Pedro", certamente o Calmon, acompanhado abaixo por nota do mesmo Pedro dizendo "N.B - o regulamento é obra do Borges de Barros", 91 indício de que a influência de Pinho não foi tão direta. Na obra Archeologia e História, de 1928, de Borges de Barros, encontra-se, inclusive, a súmula do Regulamento da Inspetoria de Monumentos Nacionais, conforme informa Cerávolo. 92 Tal como Pinho, Francisco Borges de Barros também era do Instituto Geográfico e Histórico da Bahia e foi o primeiro diretor do Museu do Estado da Bahia, entre 1918 e 1930. Desde 1915 era diretor do Arquivo Público do Estado da Bahia, no âmbito do qual foi criada a unidade que daria origem ao anexo Museu do Estado. ${ }^{93}$

No Decreto no 5.339, de 6 de dezembro de 1927, que aprova o regulamento da inspetoria, há dois artigos que se referem à possibilidade de desapropriação da circunvinzinhaça do monumento. $O$ artigo Xl prevê que "A desapropriação poderá atingir as circunvizinhanças do monumento"94 sem especificar possíveis motivações. $\bigcirc$ artigo XIII traz maior especificação e demonstra um entendimento ainda muito restrito da noção de proteção do entorno: "a desapropriação pode atingir não só o terreno que contém e o que cerca o monumento, como também o terreno necessário para a sua comunicação com a estrada que, a juízo do Governo, dê melhor acesso ao local" ${ }^{95}$ Não estão presentes, nos termos do decreto, entendimentos mais abrangentes que poderiam se relacionar com as ideias de abertura de perspectivas para 0 monumento ou de harmonização dele com o conjunto. 


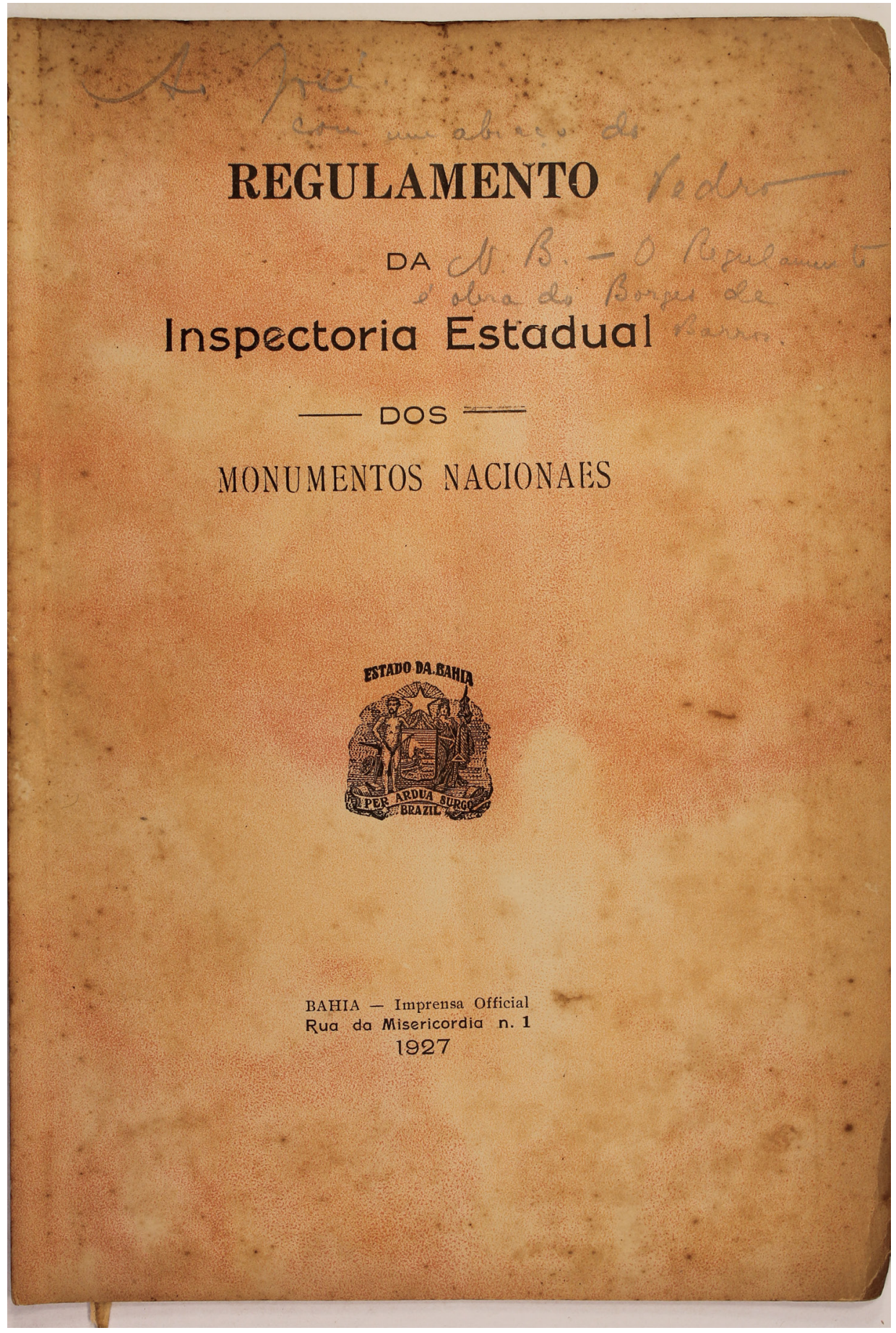

Figura 3 - Regulamento da Inspectoria Estadual dos Monumentos Nacionaes, com dedicatória a lápis de Pedro Calmon. Fonte: Fundo Wanderley Pinho, IHGB. 
96. Brasil (1930a, p. 3.023).

97. Joaquim Celso Moreira Spínola, foi deputado federal pela Bahia entre 1928 e 1929 , sendo reeleito no pleito de 1930 , tendo, em outubro desse ano, seu mandato interrompido com a extinsão dos órgãos legislativos do país. Cf. verbete sobre o deputado no Dicionário Histórico-Biográfico Brasileiro disponível em <https:// bit.ly/361wBwz>. Não conseguimos identificar o partido político de Spínola. Não há registro de filiação partidária do deputado na Câmara dos Deputados. Até o advento do Código Eleitoral de 1945 (Lei Agamenon), a filiação a partido político não era condição de elegibilidade. Fonte: Sistema de Informação Legislativa da Câmara dos Deputados Módulo Deputados. Data da pesquisa: 25 jun. 2019.

98. Cf. Brasil (1930b).

99. Ibid., 1930b, p. 2.

100. Ibid., 1930b, p. 1.

101. Ibid., 1930b, p. 2.
Pelo exposto, percebemos que pesquisas mais amplas e internacionais para compor o projeto de lei de 1930 parecem ter sido determinantes para a atualidade do projeto de Wanderley Pinho e para uma aproximação mais efetiva com relação a uma sensibilidade que já começava a se construir desde os anos 1910 e que se mostrava bastante madura em 1925, quando do pronunciamento sobre a demolição da Sé, e que já se esboçava legalmente de forma muito tímida na legislação estadual.

\section{A TRAMITAÇÃO DO PROJETO E A OPOSIÇÃO AO GOVERNO DE GETULIO VARGAS}

Pinho apresentou seu projeto no dia 29 de agosto de 1930, depois de seis anos como deputado federal, tendo uma atuação na defesa do patrimônio em seu estado natal iniciada desde o final da década de 1910, como vimos anteriormente.

No Diário do Congresso Nacional, lê-se que Pinho depositou o projeto na mesa sem realizar a defesa deste, anunciando que o faria oportunamente. ${ }^{96}$ Seu projeto chegou a receber em pouco mais de um mês, no dia três de outubro, o parecer da Comissão de Constituição e Justiça, sendo o relator o deputado Celso Spínola, conterrâneo de Pinho. ${ }^{97}$ No documento, Spínola informa que o projeto foi encaminhado para as comissões de Constituição e Justiça e de Finanças, sendo ele o relator da primeira comissão. ${ }^{98}$

O parecer de Spínola reforça a importância de uma legislação federal para não "deixar apenas a cargo dos Estados da nossa Federação as providências que a riqueza histórica e artística do Brasil está a exigir", 99 situando a criação das inspetorias da Bahia e de Pernambuco como decorrentes do fato "de não ter ainda o Congresso Nacional cuidado devidamente de legislar sobre o assunto, apesar da competência que the é atribuída pela Constituiçao Federal [...]". ${ }^{100}$ Marcando a importância do projeto de Pinho por "atender a essa justa aspiração nacional", já atendida em países que qualifica como civilizados e cultos, Spínola propõe oito emendas a ele.

O relator não rejeita a previsão de desapropriação por utilidade pública prevista como medida de proteção de um imóvel catologado, desde que mediante indenização prévia. Para ele, mesmo sendo esse um novo caso a motivar desapropriação, para além dos já previstos no Código Civil, "não há inconveniente, nem inconstitucionalidade no artigo do projeto que consigna mais esta medida excepcional, para a proteção ou salvação que se tem em vista". ${ }^{101} \bigcirc$ direito de preferência dado aos governos não é questionado, mas 
sim a possibilidade de, no caso de dúvida sobre o valor da coisa oferecida à venda, ser o preço estabelecido pela entidade de proteção federal ou repartições congêneres estaduais. São ajustes no projeto de Pinho para evitar o que o relator entende como "medidas acauteladoras do direito de propriedade contra o arbítrio dessas repartições". 102 Preocupa o relator, também, a força dada por Pinho a essas ditas repartições em detrimento do poder da administração municipal, quando previa ações independentes quando essas administrações se recusassem às medidas aconselhadas.

Spínola não deixa de mencionar a previsão de vínculos legais à vizinhança dos imóveis catologados no projeto. $\bigcirc$ trecho em que trata do assunto é muito sintético, mas contém um tom de apoio, mesmo prevendo a importância de certas atenuações ou modificações, as quais não especifica:

$\bigcirc$ projeto, nos arts. 12 e seguintes estabelece várias medidas referentes aos imóveis catalogados e aos situados nas suas vizinhanças, e proíbe a exportação para o estrangeiro das coisas móveis catalogadas. São outras tantas restrições ao direito de propriedade, que as legislações dos povos cultos, em se tratando desta matéria, e atendendo à necessidade de defesa do patrimônio histórico e artístico, têm admitido, e que nós, se quisermos legislar com eficiência sobre assunto, temos também que adotar, para a defesa do nosso patrimônio, que precisa ser zelado e protegido. Entretanto, tais restrições talvez possam ser atenuadas, ou mesmo modificadas, sem prejuízo do projeto. ${ }^{103}$

Antes de fechar o parecer, o relator registra maior discordância ao tema das penas previstas, para ele atentatórias do direito de propriedade e do livre exercício do comércio. Questiona o arbitramento de valores, as previsões de fechamento das casas comerciais e de desapropriação sem indenização. ${ }^{104}$

Spínola encerra o documento conferindo o parecer de que o projeto seja submetido à discussão e aprovação da Câmara "com as emendas que acompanham o presente parecer, além de outras que se compromete a apresentar no plenário e forem sugeridas pela discussão do projeto". ${ }^{105}$

De qualquer maneira, a tentativa de Pinho ficou sem efeito, pois ainda em outubro houve a dissolução do Congresso Nacional, confirmada com o decreto n. 19.398 de 11 de novembro.

Pinho tinha sido eleito nesse mesmo ano. Era sua terceira legislatura. Foi eleito pela primeira vez em 1924, como apontado anteriormente, sendo reeleito em 1927. Ele vinha de uma família de importantes políticos. ${ }^{100}$ Seu pai, João Ferreira de Araújo Pinho (185 1-1917) foi presidente da província de Sergipe e governador da Bahia. Seu avô materno, João Maurício Wanderley (1815-1889), o barão de Cotegipe,
102. Ibid., 1930b, p. 3.

103. Ibid., 1930b, p. 3 .

104. "As penas cominadas aos infratores dos dispositivos criados pelo projeto em apreço, consistentes em geral em multas elevadas, baseadas no valor das coisas catalogadas, móveis ou imóveis, devem merecer especial atenção da Câmara dos Srs. Deputados. O projeto, neste ponto delicado, está a merecer alguns reparos desde o arbitramento do valor da propriedade, para os efeitos das multas e outros consignados no projeto, o fechamento das casas comerciais, que negociarem com objetos de arte e antiguidade, a desapropriação sem indenização alguma (artigo 24, $2^{\mathrm{a}}$ parte), que é confisco, até o próprio confisco, expressamente admitido pelo artigo 27 do citado projeto. São medidas violentas, atentatórias do direito de propriedade e do livre exercício do comércio que precisam ser retiradas do projeto, ficando somente as penas pecuniárias." Ibid., 1930b, p. 4.

105. Ibid., 1930b, p. 4.

106. Para textos em homenagem a Pinho em ocasião de seu falecimento, cf. Lacombe (1968); Calmon (1968); Mendonça (1968); Martins Filho (1968). Para texto de homenagem escrito em ocasião do centenário de Pinho, cf. Viana Filho (1991); cf., ainda, texto de Nascimento (1978) dedicado a Pinho e com tom de homenagem. Dados biográficos podem ser vistos em Mattos (1990). 
107. Sobre a concepção de história em Pinho, na qual se destaca o enfoque biográfico, cf. Silva (2000), particularmente o capítulo 7.

108. Silva (2000, p. 23).

109. Ibid., 2000, p. 23.

110. Cf. Panfleto Às Urnas, às Urnas, 1930. Há mais dois folhetos referentes à campanha de 1930. Para tanto, cf. as seguintes notações arquivísticas do Museu Histórico Nacional: WPpl 36 / 66.496 e WPpl $38 / 66.498$. biografado por Pinho, 107 teve grande destaque na administração da província da Bahia e na administração imperial. Foi deputado em diversas legislaturas, além de presidente da província da Bahia, ministro e secretário de estado dos Negócios da Marinha, da Fazenda, dos Estrangeiros, Império e Justiça. Foi na sua presidência no Conselho dos Ministros entre 1885 e 1889 que foi aprovada a Lei dos Sexagenários, conhecida como Lei Saraiva-Cotegipe.

Pinho candidatou-se em 1930 pelo Partido Republicano da Bahia, na chapa situacionista de apoio a Júlio Prestes (presidente) e Vital Soares (vice-presidente).

Paulo Santos Silva ${ }^{108}$ observa como, às vésperas de 1930, a Bahia experimentava uma considerável estabilidade política, pois se havia chegado a um acordo entre as facções lideradas por Otávio Mangabeira e por Francisco Marques de Góes Calmon. Foi nesse contexto que surgiu, em 1927, o Partido Republicano da Bahia. Em meio a esses arranjos, consegue-se que Vital Soares, eleito para governar a Bahia no quadriênio de 1928 a 1932, renunciasse e fosse lançado como vice-presidente de Júlio Prestes. Para Santos Silva,

Com essas composições, as lideranças do estado recuperavam uma posição de destaque para a Bahia, situação já experimentada no governo de Prudente de Morais (1 8941897), ocasião em que também um baiano, Manoel Vitorino, ocupou a vice-presidência da República. A transição governamental de 1930 conduziria a Bahia a uma posição de relevo no cenário político nacional, caso a chapa situacionista vencesse. ${ }^{109}$

Panfleto de campanha de Pinho dirigido aos eleitores de Santo Amaro, sua cidade natal e importante base política, corrobora a interpretação de Silva. Nessa peça de propaganda, que chama o eleitor a votar em Júlio Prestes, Vital Soares, João Mangabeira (senador) e Pinho (deputado), consta o seguinte apelo:

Não votar a $1^{\circ}$ de Março é um crime contra a Pátria e uma prova de desamor à Bahia.

$[\ldots]$

Prova de desamor à Bahia porque quando a Bahia retoma o seu antigo ascendente na federação e se vê acatada e galardoada; quando depois de tantos anos figura um bahiano na chapa presidencial; quando sua políica se unifica coesa; quando é preciso mostrar pelo número de votos o valor dessa coesão - não votar é como ser indiferente ao bem do torrão amado. ${ }^{110}$ 
Para Silva, "Não havia porque as elites políticas estaduais aderir a um movimento ['Revolução de 1930'] que desalojava seus membros mais representativos do aparelho de Estado". ${ }^{111}$

No acervo do Museu Histórico Nacional, na Coleção Wanderley Pinho, encontra-se uma anotação de Pinho relatando, em forma de diálogos, o expediente que teve com o então presidente Washington Luís, no dia 11 de outubro de 1930, poucos dias antes do presidente ser deposto. ${ }^{112}$ Pinho começa o manuscrito contextualizando a motivação de sua ida ao gabinete do chefe de Estado. Tinha sabido, a poucos dias, da "revolução" em Minas Gerais e no Rio Grande do Sul. Preocupado com a Bahia, havia feito um exame de consciência que apontava para seu dever de voltar a sua base: "Devia estar junto dos amigos, orientá-los, levantar-lhes o ânimo, organizar a defesa de S. Amaro e outros municípios, agir e não permanecer no Rio como um espectador". 113 Anota, contudo, sua dúvida, diante dos tantos deveres no Rio de Janeiro. Elenca os deveres de deputado, de membro da comissão de Finanças e de relator de um orçamento em votação. Teria sido essa a grande motivação para que consultasse o presidente: queria ouvir-lhe "instruções" que dirimissem sua dúvida.

Na sequência, inicia-se a reprodução do diálogo. Pinho, após ouvir do presidente que deve, sim, retornar à Bahia, pede licença para solicitar mais forças para o seu estado. Considera que "a que lá está é insuficiente para a sua defesa. Nós precisamos ter lá artilharia que os rebeldes não têm e representa para nós vantagem". 114 Pinho transcreve uma fala exaltada do presidente, em resposta a uma afirmativa sua de que "os armamentos estão com os rebeldes que assim podem organizar um exército contra a Bahia". ${ }^{115} \bigcirc$ presidente teria respondido com um "- ora! Qual exército. $\bigcirc$ que há são forças irregulares que recuarão [ilegível]". 116 Diante das insistências de Pinho, inclusive solicitando avião, o presidente, no relato de Pinho, aparece como alguém incomodado. A expressão de incômodo força Pinho a assegurar que não teria qualquer ideia derrotista ou dúvida da vitória. $\bigcirc$ presidente, nesse registro feito por Pinho, parece mais otimista do que ele e teria referido que estariam chegando ao Palácio da Guanabara boas notícias. $\bigcirc$ relato acaba com um "- Boa Viagem" da parte do presidente a Pinho. ${ }^{117}$

Wanderley Pinho foi um dos articulistas da campanha constitucionalista na Bahia por meio da Liga de Ação Social e Política. ${ }^{118}$ Depois compôs a Concentração Autonomista da Bahia, grupo de oposição ao governo de Getulio Vargas. Como bem explica Paulo Santos Silva,
111. Silva (2000, p. 23).

112. Pinho (1930).

113. Ibid., folha 4 .

114. Ibid., folha 7 .

115. Ibid., folha 8 .

116. Ibid.

117. Ibid., folha 12 .

118. Silva (2000, p. 32). 
119. Ibid., 2000, p. 13.

120. Brasil (1935, p. 4679 a 4681).

121. Ibid., 1935, p. 4679).

122. Consultamos os Annaes da Câmara dos Deputados, em pesquisa via Biblioteca Digital da Câmara dos Deputados.

123. Relatório anual de tramitação das proposições da Câmara dos Deputados. Inclui mapas demonstrativo e administrativo das discussões e do andamento das propostas na Câmara dos Deputados. Não houve publicação nos seguintes anos: 1870 , 1871, 1876, 1878, 1881, 1890, 1931-1945.

124. Sobre Capanema no poder, cf. Schwartzman; Bomeny; Costa (2000).
Os grupos de oposição ao governo Vargas e ao interventor Juracy Magalhães foram os responsáveis pela construção de uma das mais duradouras correntes políticas até então existentes: a Concentração Autonomista da Bahia. A partir de sua fundação, em 1933, esta corrente tornou-se uma força aglutinadora; reuniu e conferiu unidade às diversas facções baianas em torno da reivindicação da autonomia do estado frente ao poder central. Desarticulada em 1937, em decorrência da implantação do Estado Novo, reapareceu em 1945, reforçada e ampliada, assumindo a liderança na condução da luta contra o governo Vargas. ${ }^{119}$

Seria apenas em 1935, como deputado federal eleito, depois de ter os direitos políticos restituídos pela Constituição de 1934, que Araúio Pinho voltaria à Câmara Federal. Nesse ano, reapresenta seu projeto, agora de número 259.

O projeto em quase nada se distingue da versão de 1930. Pinho não modifica as penalidades enfaticamente criticadas pelo relator Spínola em 1930. Há um acréscimo na redação no artigo décimo, para torná-lo mais claro. Na composição do conselho consultivo, há mudança do ministério que indicaria os dois colecionadores de antiguidades ou diretores de museus particulares: anteriormente o da Justiça e, em 1935, o da Educação. Há supressão dos parágrafos de dois a quatro do artigo $n^{0} 20$, omitindo detalhamentos quanto à composição dos funcionários da Inspetoria. $\bigcirc$ artigo $3^{\circ}$, que define os imóveis considerados sujeitos aos efeitos da lei, recebe um acréscimo na parte dedicada aos bens integrados. Pinho procura especificar ainda mais os elementos passíveis de proteção, que, para além dos já previstos, como as cimalhas, os frisos, as arquitraves, as portas, as janelas e as colunas, são agora também os azulejos, os tetos, as obras de marcenaria e as pinturas murais. Continua, ainda, a menção mais genérica aos ornatos. ${ }^{120}$

Está registrado no Diário do Poder Legislativo que, na sessão de 17 de setembro, o projeto de Pinho "é lido, considerado objeto de deliberação e enviado às Comissões de Constituição e Justiça e de Educação e Cultura". ${ }^{21}$ Não encontramos registros dessa tramitação. ${ }^{122}$ A Coordenação de Relacionamento, Pesquisa e Informação (Corpi) da Câmara dos Deputados informa que a coleção Tramitação das Proposições de 1869 a 1947 não está disponível para o ano de 1935. ${ }^{123}$

Como é bem sabido, em 1936, o então ministro da Educação, Gustavo Capanema, ${ }^{124}$ político mineiro saído do meio intelectual de Belo Horizonte, tendo como chefe de gabinete Carlos Drummond de Andrade, abrirá, no processo de constituição da lei de proteção do patrimônio nacional, espaço para Mário de Andrade, convidado a preparar um esboço, e Rodrigo Melo Franco de Andrade, diretor do Sphan, que dará forma final à proposta que será encaminhada ainda nesse ano à Câmara dos Deputados. 
Como já referido na introdução, em 1936, quando o Brasil vivia ainda um regime constitucional, o projeto de Pinho é citado na apresentação que a Comissão de Educação e Cultura da Câmara dos Deputados faz à Comissão de Justiça do Projeto n 511.125 Constam como autores da apresentação, reunidos na Sala das Comissões em 18 de novembro de 1936, o relator, Martins Soares, além de Edgar Sanches, Lontra Costa, Antônio de Góes, Raul Bittencourt, Vandoni de Barros e Silva Costa. Na página 1 dessa apresentação é dado destaque ao anteprojeto de Mário de Andrade. Na página 2, aparecem referências à importância da consulta ao anteprojeto de Jair Lins, ao projeto de Pinho, já rapidamente citado à página 1, à legislação em vigor no país e às legislações estrangeiras, especialmente a francesa e a mexicana. Não parece ter havido uma participação mais direta de Pinho no processo.

Afastado do centro de tomada de decisão pelo Estado Novo em 1937 e com o DL 25/37 já expedido, Pinho parece ter colaborado com a regional do Sphan em Salvador. Segundo Dócio, 126 ele foi colaborador do órgão nos estudos para o desenvolvimento de "diversos processos de tombamento", uma atuação que, segundo a autora, transparece na composição do seu livro História de um Engenho do Recôncavo: Matoin, Novo, Caboto, Freguesia (1552-1944). Na lista de bens tombados pelo Iphan, encontramos o conjunto rural do Engenho Freguesia composto por sobrado, fábrica de açúcar e Capela de Nossa Senhora da Piedade, tombado em 1944. É esse engenho o objeto da pesquisa de Pinho, publicada em 1946. Mattos ${ }^{127}$ informa que Wanderley Pinho chegou a fazer indicações a Rodrigo Melo Franco de Andrade sobre bens da Bahia para tombamento e recebeu dele aval para obter reproduções fotográficas da instituição. Utiliza, para tanto, correspondências trocadas entre Godofredo Filho - que estava à frente do Serviço na Bahia - e Rodrigo Melo Franco de Andrade, assim como entre Godofredo Filho e Pinho, ambas encontradas no Arquivo Técnico da regional do Iphan/BA e datadas, respectivamente de 1938 e 1945.

Pesquisando a Revista do Sphan até o seu número 16, de 1968, a partir do qual se interrompe a supervisão de Rodrigo Melo Franco de Andrade, por sua morte (maio de 1969), encontra-se em um dos primeiros números, o de número 4, de 1940, um artigo de autoria de "W.P.". É o único dos 13 artigos em que a autoria aparece identificada apenas com as iniciais, o que permite levantar a hipótese de uma colaboração não dada a grandes visibilidades. $\bigcirc$ artigo é um estudo de documentos textuais de antes de 1600, vistos como fontes privilegiadas para uma aproximação a uma correta nomenclatura a ser dada pelo serviço a mobiliários, vestuários, joias e alfaias dos tempos coloniais. Na revista disponibilizada on-line no portal do Iphan, vê-se, abaixo do "W. P." localizado na página 269, o nome
125. Cf. Brasil (1936). 126. Dócio (2014, p. 99). 127. Mattos (2014, p. 46). 
128. Cf. em <http://docvirt. com/docreader.net/DocReader.aspx?bib=reviphan \&pa gfis=8429>

129. Soeiro (1969, p. 10).

130. Cf. Mangabeira (1939; 1940).

131. Silva (2000, p. 42). Mangabeira será condenado em dezembro de 1940 pelo Tribunal de Segurança Nacional por matéria contrária ao regime e conseguirá habeas corpus em abril de 1945. Cf. referência à condenação e habeas corpus em Silva (2000, p. 43-44).

132. Dócio (2014, p. 99)

133. Mattos (2014, p. 59). manuscrito "José Wanderley de Araújo Pinho"128 e, na introdução da edição de número 17, Renato Soeiro menciona o nome de todos os colaboradores dos 16 primeiros números da revista, referindo-se a Wanderley Pinho como um deles. ${ }^{129}$

Documentos da coleção Wanderley Pinho do Museu Histórico Nacional referentes a esse momento da publicação do artigo na Revista do Sphan referem-se à postura oposicionista de Pinho ao governo Vargas. São textos do líder baiano Otávio Mangabeira, escritos durante seu exílio, em 1939 e em 1940. O primeiro, intitulado "À Nação Brasileira, um Protesto a Propósito da Comemoração no Brasil, do Cinquentenário da República, pelos que Destruíram no País as Instituições Republicanas", e o segundo, intitulado "1930-1940, um Decênio, no Brasil, de Degradação Nacional: em Nome e por Desagravo da Atual Geração Brasileira". ${ }^{30}$

Silva situa a importância de Otávio Mangabeira no meio oposicionista baiano e a campanha pela sua anistia:

No âmago da luta dos "autonomistas" estava a conquista da anistia, ou melhor, da anistia para Otávio Mangabeira. Embora nos quinze anos precedentes Juracy Magalhães [interventor] tenha assegurado para si um lugar no seio da classe dirigente baiana, tornando-se um aceito, este fato não apagou a presença do ex-chanceler do governo Washington Luiz. Ao contrário, redimensionou seu perfil, conferindo-the o caráter de símbolo da resistência democrática em razão das perseguições de que fora vítima. Apesar de sofrer dois exílios - de 1930 a 1934 e de 1937 a 1945 -, o líder autonomista, mesmo à distância, manteve-se entre as forças políticas baianas com notável poder de aglutinação sobre as tendências e facções locais. Seu retorno do exílio, em 1945, parecia consistir no elemento que faltava para que a oposição triunfasse no estado. Trazê-lo de volta tornou-se um imperativo para as forças "autonomistas". A campanha pela anistia do seu nome foi um dos eixos em torno do qual girou a luta pela "redemocratização" na Bahia.

Em 1947, dois anos depois da anistia e fim do Estado Novo, Pinho foi prefeito de Salvador no governo de Otávio Mangabeira ${ }^{131}$ (eleito em 1946), ficando até 1951. Dócio ${ }^{132}$ sublinha uma aproximação do governo municipal com - Sphan, com parcerias a exemplo de uma proposta de desapropriação da Casa dos Sete Candeeiros, para criação de um Museu da Cidade e instalação da própria Repartição dos Serviços de Defesa do Patrimônio Histórico e Artístico Nacional. Mattos ${ }^{133}$ aponta que a solicitação de desapropriação feita a Pinho partiu de Pedro Calmon, em 1950, quando era Ministro da Educação e Saúde. 
A redação proposta por Pinho, apesar de provavelmente ter sido 136. Ibid., 1995, p. 94. referência para o DL 25/37, como mencionado por Rodrigo Melo Franco de Andrade, não foi incorporada plenamente.

Sant'Anna ${ }^{134}$ observa que, se a redação do artigo 18 do decreto-lei (acima parafraseado) avança consideravelmente em relação à proposta de Jair Lins, ficou muito aquém das disposições constantes do projeto de Wanderley Pinho. Lembremos que o artigo 18 afirma que "não se poderá, na vizinhança da coisa tombada, fazer construção que the impeça ou reduza a visibilidade".

A autora ${ }^{135}$ levanta algumas hipóteses para justificar os motivos de uma "redação tão tímida" para o artigo 18. A primeira se vincularia ao problema da limitação do direito de propriedade. A função social da propriedade, como visto anteriormente, foi instituída pela Constituição de 1934 e confirmada e ampliada pela Constituição de 1937. Era, então, algo recente e, "de certa forma, apenas um princípio constitucional, ainda sem muita objetivação ou concretização mediante legislação ordinária". ${ }^{136}$

Outra razão estaria relacionada "à própria noção de valorização do bem tombado vigente na época". Sant'Anna ${ }^{137}$ entende que, no texto do projeto de Wanderley Pinho, "a intenção principal da proteção da ambiência era garantir o desimpedimento da perspectiva do bem. Era destacá-lo na paisagem, menos do que inseri-lo num contexto urbano homogêneo $[\ldots]^{\prime \prime}$.

A palavra "moldura", presente no artigo de Pinho, agora relacionada à jurisprudência italiana, lança outras hipóteses, antes não possíveis: Pinho, ao inserir essa palavra, adicionalmente à palavra "perspectiva", buscaria evitar que houvesse uma leitura restritiva da lei como tinha ocorrido na ltália? Ou, mesmo sem conhecer os embates jurisprudenciais italianos, entendeu por bem ampliar a proteção, para além da "perspectiva" mais direta ao bem, envolvendo sua "moldura"? Nesse último caso, o que teria significado, para Pinho, a palavra "moldura"?

É interessante observar que o termo "visibilidade", escolhido para enfrentar a questão da proteção do entorno no DL 25/37, e desacompanhado da noção de "moldura" proposta por Pinho, provocará as mesmas dúvidas quanto à sua capacidade conservacionista, tal como o termo "perspectiva" na Itália. 
138. Motta; Thompson (2010).

139. "Evidentemente não se trata da simples visibilidade física, mas da visibilidade de um ponto de vista estético ou artístico, porque está em causa a proteção de um monumento de arte: a igreja histórica integrada num conjunto paisagístico (...)" Leal apud Motta (2010, p. 111).

140. Queirós apud Motta (2010, p. 111)

141. Sant'Anna (1995, p. 101).

142. Meireles, 1977 apud Sant'Anna (1995, p. 102).

143. § 2o Equiparam-se aos bens a que se refere o presente artigo e são também sujeitos a tombamento os monumentos naturais, bem como os sítios e paisagens que importe conservar e proteger, pela feição notável com que tenham sido dotados pela natureza ou agenciados pela indústria humana. Cf. (Brasil, 1937b).
Como amplamente documentado na publicação do Iphan, Entorno de Bens Tombados, ${ }^{138}$ casos como o da igreja de Nossa Senhora da Glória do Outeiro, no Rio de Janeiro, e do Convento de São Francisco de João Pessoa, na Paraíba, levaram a todo um embate jurisprudencial.

No caso do Outeiro da Glória, firmou-se jurisprudência sobre a noção de visibilidade. No voło do ministro João José de Queirós, emitido em 1954 e depois reforçado pelo voto favorável ao Iphan, em 1965, do ministro Victor Nunes Leal, ${ }^{139}$ amplia-se o entendimento para além do de visibilidade óptica.

Para Queirós,

O conceito de visibilidade para fins da proteção legal dispensada às coisas de valor histórico e artístico não se limita à simples percepção ótica. Determinada obra poderá permitir a visão física, em nada a reduzindo, no sentido material, quanto ao bem tombado. Esse, entretanto, embora continuando fisicamente visível, poderá vir a ser altamente prejudicado por construção que se faça em sua vizinhança, quer como resultado da comparação entre as respectivas dimensões, quer por prejudicar o novo edifício, o conjunto paisagístico que emoldura, tradicionalmente, o bem tombado. Não é só isso. A própria diferença de estilos arquitetônicos, quebrando a harmonia do conjunto imprescindível à obra de arte integrada no espaço urbano, poderá, no sentido legal, reduzir a "visibilidade" da coisa protegida. Esse é o espírito do artigo 18 do Decreto-lei 25.140

Essa consideração é muito próxima àquela da Corte de Cassação Italiana em 1920, aqui apresentada.

Sant'Anna ${ }^{141}$ assinala como, apesar da jurisprudência, a questão nunca se tornou pacífica e traz, no âmbito de entendimentos de juristas, visões como a de Paulo Affonso Leme Machado, que entende que o artigo 18 resguarda apenas a visão do bem tombado. Para ela, de todo modo, por força da jurisprudência firmada em vários casos judiciais e também em decorrência de a opinião da maioria dos juristas ser favorável "à interpretação larga dos conceitos criados no artigo 18", prevaleceria a doutrina expressa por Hely Lopes Meireles nos seguintes termos: "O conceito de visibilidade para fins da Lei de Tombamento é amplo, alcançando não só a tirada da vista da coisa tombada, como a modificação do ambiente ou da paisagem adjacente, a diferença de estilos arquitetônicos, e tudo o mais que contraste ou afronte a harmonia do conjunto, tirando o valor histórico ou a beleza original da obra protegida." 142

No DL 25/37, os "sítios" e "paisagens", tanto naturais quanto agenciados pela indústria humana, serão inseridos, ${ }^{143}$ dando conta da dimensão urbana 
prevista por Pinho, numa redação que se aproxima dos termos da proposta de Pinho, ao incorporar o termo "sítios", e do anteprojeto de Mário de Andrade.

De forma geral, com o presente artigo, procurou-se respaldar hipóteses de vínculos entre o DL 25/37 e as proposições do deputado baiano Wanderley Pinho em relação ao tema da proteção do entorno. Procurou-se, também, aprofundando a leitura do texto de Pinho, verificar semelhanças deste com textos de lei e decisões de jurisprudência internacional, de forma a iluminar de maneira mais detalhada os diálogos que permitiram ao deputado dar concretude a ideias reconhecidas pelos autores citados na introdução como à frente do seu tempo. Além da proteção do entorno, viu-se a aproximação de Pinho à ideia de proteção de sítios e edificações em conjunto, tal como presente na legislação da Espanha.

As tensões político-partidárias, rapidamente abordadas, procuraram iluminar o espaço secundarizado recebido pelo projeto de Pinho, em detrimento do grupo vinculado a Capanema. A ausência de informações sobre a possível reapresentação do projeto em 1935 e sua tramitação não permitem maiores aprofundamentos sobre esse processo. De qualquer forma, percebe-se que Pinho, apesar de toda a oposição política ao governo Vargas, não deixou, durante o Estado Novo, de apoiar iniciativas do Serviço e nem Rodrigo Melo Franco deixou de convidá-lo para colaborações, como a da revista.

No âmbito das ideias, numa perspectiva de recorte internacional, a proposta de Pinho aparece como tímida em relação à legislação espanhola, e possivelmente muito perspicaz em relação ao debate italiano. Independentemente dos arranjos comparativos que se desenhem pelo historiador, espera-se, com o artigo, que se vislumbrem mais fontes na história da gênese da proteção do patrimônio no Brasil, a partir da incorporação de leis internacionais, e se reconheçam os esforços de agentes como Pinho, que, indiretamente, parecem ter contribuído sobremaneira, para além das dificuldades de espaço político, no sentido de uma proteção para além do monumento. 


\title{
REFERÊNCIAS
}

\author{
FONTE MANUSCRITA
}

PINHO, Wanderley. Manuscrito 12 p. mss. [Anotação do encontro que teve o titular com o presidente Washington Luís após o movimento que ocorreu em 11 de outubro de 1930]. Acervo: Museu Histórico Nacional. Fundo Wanderley Pinho. Série Anotações e Cópias. Notação arquivística: WPac 03 / 66.654/.

Fontes impressas

ABREU, Jaime Cunha da Gama. A conservação da Sé impõe-se. Um plano bem esboçado conciliará todos os interesses em jogo. Documento datilografado, datado de 17.10.1928. Acervo: Museu Histórico Nacional. Coleção Wanderley Pinho. Série Publicações Diversas. Notação arquivística: WPm 39/ 66.632. 5 folhas.

BARBAN, Caterina Moggian. La legislazione relativa ai settori di salvaguardia in Spagna. In: ZUCCHINI, Alessandro; CALABI, Donatella; VASSALO, Eugenio (Org.). Modulo1a - Studio sulle normative catalografiche e uniformazione dei metodi di acesso a tali informazione. Modulo $1 b$ - Studio comparato dela legislazione relativa ai settori di salvaguardia in Europa. Veneza: Copertina, gráfica e impaginazione: Gianni Plebani, 2002, p. 99-126. [Relatório científico].

BAHIA (Estado). Regulamento da Inspectoria Estadual dos Monumentos Nacionaes. Bahia: Imprensa Official, 1927. Acervo: IHGB. Fundo Wanderley Pinho. Notação: DL 1570.10. Descrição: Legislações usadas para elaboração do projeto.

BRASIL (1930a). Congresso Nacional. Diário do Congresso Nacional. Rio de Janeiro: Imprensa Nacional, n. 102, 30 de agosto de 1930.

BRASIL (1930b). Câmara dos Deputados. Comissão de Constituição e Justiça. Projecto n. 230, de 1930, que organiza a defesa do patrimônio histórico e artístico nacional. Parecer do Sr. Celso Spínola. Rio de Janeiro: Imprensa Nacional, 1930. 5 fl. Fonte: Fundação Getulio Vargas (FGV). Centro de Pesquisa e Documentação de História Contemporânea do Brasil (CPDOC). Fundo Gustavo Capanema. Classificação do documento: GC-1585f.

BRASIL. Câmara dos Deputados. Diário do Poder Legislativo. Rio de Janeiro, anno II, n. 120, 18 set. 1935 . 
BRASIL. Câmara dos Deputados. Projecto n. 511 - 1936. [Organiza a Proteção do Patrimônio Histórico e Artístico Nacional. Com Parecer da Commissão de Finanças Favorave [sic] ao projeto da Commissão de Educação]. Rio de Janeiro: Imprensa Nacional, 1936. 26 folhas. Acervo: IHGB. Fundo Wanderley Pinho. Notação arquivística: DL 1570.10.

BRASIL (1937a). Senado Federal. Comissão de Constituição e Justiça do Senado. [parecer sobre o Projeto $\mathrm{n}^{\circ}$ 239, de 1937]. Documento datilografado, s/d. 5 folhas. Acervo: Iphan - Noronha Santos, caixa L-01, pasta 01/01.

BRASIL (1937b). Decreto-lei $n^{\circ}$ 25, de 30 de novembro de 1937. [Organiza a proteção do patrimônio histórico e artístico nacional]. Disponível em: <https://bit.ly/2QklrMd>. Acesso em: 3 jan. 2019.

BRASIL. Iphan. 2019 [1964]. Carta de Veneza. [Tradução para o português]. Disponível em: <https://bit.ly/2uzqb69>. Acesso em: 3 jan. 2019.

ESPANHA. Ministério de Instrucción Pública y Bellas Artes. Real Decreto-ley de 9 de agosto de 1926. [Defensa de la riqueza monumental y artística de España]. Madri: Ministerio de Instrucción Pública y Bellas Artes / Talheres del Instituto Geográfico y Catastral, edición especial, 1926. Acervo: IHGB. Fundo Wanderley Pinho. Notação: DL 1570.10. Descrição: Legislações usadas para elaboração do projeto.

ITALIA. Lei n. 185, de 12 de junho de 1902. [Sobre a conservação dos monumentos e dos objetos de antiguidade e arte]. Gazzetta Ufficiale, Roma, 27 jun. 1902, n.149.

ITALIA. Lei n. 364, de 20 de junho de 1909. [Estabelece e fixa normas para a inalienabilidade das antiguidades e das belas artes]. Gazzetta Ufficiale, Roma, 28 jun. 1909, n. 150.

ITALIA. Lei n. 688, de 23 de junho de 1912. [Traz modificações à lei de 20 de junho de 1909 , n. 364, para as antiguidades e belas artes]. Gazzetta Ufficiale, Roma, 8 jul. 1912, n.160.

ITALIA. CORTE DI CASSAZIONE DI ROMA. Udienza 15 feb. 1920; Pres. Tommasi, Est. Millo, P.M. De Carolis (concl.conf.); Lilli (Avv. Galli, Schupper) c. Ministero della pubblica istruzione (Avv. Biamonti, Beltrame-Quattrocchi). In: Il Foro Italiano, vol. XLV, anno 1920, parte I, p. 201. Roma: Società Editrice del Periodico Il Foro Italiano.

ITALIA. Lei n. 778, de 11 jun. 1922. [Dispõe sobre a tutela das belezas naturais e dos imóveis de particular interesse histórico]. Gazzetta Ufficiale, Roma, 24 jun. 1922, n. 148.

ITALIA. Lei n. 1.497, de 29 jun. 1939. [Dispõe sobre a proteção das belezas naturais]. Gazzetta Ufficiale, Roma, 30 jun. 1939, n. 151. 
ITALIA. Lei n. 1.089 , de $1^{\circ}$ jun. 1939. [Dispõe sobre a tutela das coisas de interesse artistico e histórico]. Gazzetta Ufficiale, Roma, 8 ago. 1939, n. 184.

MANGABEIRA, Otávio. À nação brasileira, um protesto a propósito da commemoração no Brasil, do cincoentenário da República, pelos que destruíram no país as instituições republicanas. Biarritz, 2 dez. 1939. Acervo: Museu Histórico Nacional. Coleção Wanderley Pinho. Série Política. Notação: WPpl 41/ 66.501

MANGABEIRA, Otávio. 1930-1940, um decennio, no Brasil, de degradação nacional: em nome e por desagravo da actual geração brasileira. [escrito a bordo do "Exeter", em viagem de Lisboa para Nova York, 3 nov. 1940]. Acervo: Museu Histórico Nacional. Coleção Wanderley Pinho. Série Política. Notação: WPpl 39 / 66.499.

PANFLETO eleitoral. [Intitulado “Às urnas, às urnas”, incentivando os eleitores a votarem nos candidatos do Partido Republicano da Bahia, sendo eles: Júlio Prestes, Vital Soares, João Mangabeira e Wanderley Pinho, no pleito de $1^{\circ}$ de março. S/1., s/d.]. Acervo: Museu Histórico Nacional. Coleção Wanderley Pinho. Série Política. Notação arquivística: WPpl 14 / 66.474.

PANFLETO eleitoral. [Dirigido ao eleitor e ao povo santamarense de autoria do Sr. José Wanderley de Araujo Pinho fazendo campanha a favor dos candidatos Júlio Prestes e Vital Soares para serem representantes do país. Santo Amaro, fev. 1930]. Acervo: Museu Histórico Nacional. Coleção Wanderley Pinho. Série Política. Notação arquivística: WPpl 36 / 66.496

PANFLETO eleitoral. [Intitulado "Liberalismo Sanguinário", a favor dos candidatos Júlio Prestes e Vital Soares para serem representantes do país e a publicação da carta do Sr. Fausto de Almeida de Prado Penteado na qual relatava a participação do candidato Getúlio Vargas no assassinato do seu tio o Sr. Carlos de Almeida Prado Junior. S/1., s/d.]. Acervo: Museu Histórico Nacional. Coleção Wanderley Pinho. Série Política. Notação arquivística: WPpl 38 /66.498.

LIVROS, ARTIGOS E TESES

ANDRADE, Rodrigo Mello Franco de. Brasil: monumentos históricos e arqueológicos. Rio de Janeiro: Iphan/DAF/Copedoc, 2012. Fac-símile de obra originalmente publicada pelo Instituto Pan-americano de Geografia e História, México, 1952.

BRASIL. Ministério da Cultura. Proteção e revitalização do patrimônio cultural no Brasil: uma trajetória. Brasília: Sphan/Pró-Memória, 1980. Disponível em: <https://bit. ly/2GZTyUt>. Acesso em: 3 jan. 2009. 
CABRAL, Renata. A noção de "ambiente" em Gustavo Giovannoni e as leis de tutela do patrimônio cultural na Itália. 2013. 197 f. Tese (Doutorado em Teoria e História da Arquitetura) - Instituto de Arquitetura e Urbanismo, Universidade de São Paulo. São Paulo, 2013.

CABRAL, Renata; JACQUES, Paola Berenstein. O antropófago Oswald de Andrade e a preservação do patrimônio: um "devorador" de mitos? Anais do Museu Paulista, São Paulo, v. 26, 2018, p. 1-39, e 32 .

CALMON, Pedro. José Wanderley de Araújo Pinho. Discursos proferidos na sessão especial em homenagem a sua memória em 6-12-67. Revista do Instituto Histórico e Geográfico Brasileiro, Rio de Janeiro, v. 278, p. 174-176, jan./mar. 1968.

CANTARELLI, Rodrigo. Contra a conspiração da ignorância com a maldade. A Inspetoria de Monumentos de Pernambuco. Recife: Fundaj; Massangana, 2016. 238 p.

CANTARELLI, Rodrigo. Ante o vandalismo dos homens e os estragos do tempo: experimentos, preparações e invenções nas práticas de preservação do patrimônio brasileiro. 2019. Tese (Doutorado) - Programa de Pós-Graduação em História, Universidade Federal de Pernambuco. Recife, 2019.

CERAVOLO, Suely Moraes. O Museu do Estado da Bahia, entre ideias e realidades (1918 a 1959). Anais do Museu Paulista: História e Cultura Material, São Paulo, v. 19, n. 1, p.189-243, jan./jun. 2011.

CERAVOLO, Suely Moraes. A Inspetoria Estadual de Monumentos Nacionais do estado da Bahia: do discurso à ação (1927-1938). In: MAGALHÃES, Aline Montenegro; BEZERRA, Rafael Zamorano. 90 anos do Museu Histórico Nacional em debate. Rio de Janeiro: Museu Histórico Nacional, 2014. p. 122-142.

CHUVA, Márcia Regina Romeiro. Os arquitetos da memória: sociogênese das práticas de preservação do patrimônio cultural no Brasil (anos 1930-1940). Rio de Janeiro: UFRJ, 2009.

COSTA, Lúcio. Lúcio Costa, homenagem aos seus 90 anos de vida. Brasília: IBPC Notícias, Edição Especial, 27 de fevereiro de 1992.

DóCIO, Vanessa de Almeida. Sob o signo da pedra e cal: a trajetória da política de preservação do patrimônio histórico e arquitetônico no estado da Babia (1927-1967). 2014. 171 f. Dissertação (Mestrado) - Faculdade de Filosofia e Ciências Humanas, Universidade Federal da Bahia. Salvador, 2014. 
FREYRE, Gilberto. 75. Série Artigos Numerados, Diário de Pernambuco. In: FREYRE, Gilberto. Tempo de aprendiz. Artigos publicados em jornais na adolescência e na primeira mocidade do autor (1918-1926). São Paulo: Global, 2016. $1^{\text {a }}$ edição digital. Publicado originalmente em 21 set. 1924.

FREYRE, Gilberto. O Recife e as Árvores. In: FREYRE, Gilberto. Tempo de aprendiz. Artigos publicados em jornais na adolescência e na primeira mocidade do autor (1918-1926). São Paulo: Global, 2016. 1ª edição digital. Publicado originalmente em 12 nov. 1924.

GIOVANNONI, Gustavo; PITTARELLI, Giulio. Sul significato della parola prospettiva usata nella legge sulla conservazione dei monumenti. Roma: E. Calzone, 1918.

JAEN, Juan Lopez. Los centros históricos españoles entre la realidade y la legalidad. Revista Urbanismo COAM, Madri, n. 9, p. 14-24, jan. 1990.

JIMÉNEZ, María Isabel Martín. Patrimonio y paisaje en España y Portugal. Del valor singular a la integración territorial. Boletín de la Asociación de Geógrafos Españoles, n. 71, p. 347-374, 2016.

LACOMBE, Américo Jacobina. José Wanderley de Araújo Pinho. Discursos proferidos na sessão especial em homenagem a sua memória em 6-12-67. Revista do Instituto Histórico e Geográfico Brasileiro, Rio de Janeiro, v. 278, p. 171-174, jan./mar. 1968.

LEITE, Rinaldo Nascimento. Ideias de civilização e cenas de anti-civilidade em um contexto de modernização urbana. Salvador, 1912-1916. 1996. Dissertação (Mestrado em História) Programa de Pós-Graduação em História, Universidade Federal da Bahia. Salvador, 1996.

LINS, Jair. Esboço de anteprojeto de lei federal elaborado pelo jurista Jair Lins na qualidade de relator da Comissão designada em julho de 1925 pelo Presidente Mello Vianna, do Estado de Minas Gerais, para organizar a proteção do patrimônio histórico e artístico. In: IPHAN. Proteção e revitalização do patrimônio cultural no Brasil: uma trajetória. Brasília: Sphan/Pró-Memória, 1980, p. 35-45.

MAGALHÃES, Aline Montenegro. A curta trajetória de uma política de preservação patrimonial: a Inspetoria de Monumentos Nacionais, 1934-1937. Anais do Museu Histórico Nacional - v. 36 (2004). Rio de Janeiro: Ministério da Cultura, Instituto do Patrimônio Histórico e Artístico Nacional, 2004.

MAGALHÃES, Aline Montenegro. A Inspetoria de Monumentos Nacionais do Museu Histórico Nacional e a proteção de monumentos em Ouro Preto (1934-1937). Anais do Museu Paulista: História e Cultura Material, São Paulo, v. 25, n. 3, p. 233-290, set.-dez. 2017. 
MARTINS FILHO, Enêas. José Wanderley de Araújo Pinho. Discursos proferidos na sessão especial em homenagem a sua memória em 6-12-67. Revista do Instituto Histórico e Geográfico Brasileiro, Rio de Janeiro, v. 278, p. 177-180, jan./mar. 1968.

MATOS, Maria Teresa Navarro de Britto. O acervo Wanderley Pinho: um exemplo de arquivo político. Revista do Instituto Geográfico e Histórico da Babia, n. 95. Salvador: IGHB, 2000, p. 197-214.

MATTOS, Ana Teresa Góis Soares de. Nem português, nem mineiro... baiano e nacional, com todo respeito: a atuação da Bahia no campo do patrimônio brasileiro. 2014. Dissertação (Mestrado Profissional em Preservação do Patrimônio Cultural) - Instituto do Patrimônio Histórico e Artístico Nacional, 2014. 145f.

MATTOS, Waldemar. Notas biográficas. In: PINHO, José Wanderley de Araújo. Coletânea de textos históricos. Salvador, Artes Gráficas, 1990.

MENDONÇA, Marcos Carneiro de. José Wanderley de Araújo Pinho. Discursos proferidos na sessão especial em homenagem a sua memória em 6-12-67. Revista do Instituto Histórico e Geográfico Brasileiro, Rio de Janeiro, v. 278, p. 176-177, jan./mar. 1968.

MOTTA, Lia; THOMPSON, Analucia. Entorno de bens tombados. Rio de Janeiro: Iphan/ DAF/Copedoc, 2010.

NASCIMENTO, Anna Amélia Vieira. O mestre, o historiador, o fidalgo Wanderley Pinho. Revista do Instituto Geográfico e Histórico da Babia, n. 87. Salvador: IGHB, 1978, p. 227-238.

NOGUEIRA, Alice Alves. Ramalho Ortigão e o Culto dos Monumentos Nacionais no Século XIX. 2009. 586 f. Tese (Doutorado em História) - Instituto de História da Arte, Departamento de História, Faculdade de Letras, Universidade de Lisboa. Lisboa, 2009.

ORTIGÃO, Ramalho. O culto da arte em Portugal. Lisboa: Antônio Maria Pereira LivreiroEditor, 1896.

PANE, Andrea; CABRAL, Renata. Le parole della tutela: "prospettiva", "luce" e "ambiente" nel dibattito culturale e normativo per la salvaguardia a scala urbana in Italia, 19021939. In: ADORNO, Salvatore; CRISTINA, Giovanni; ROTONDO, Arianna. VI Congresso AISU. Visibile Invisibile: percepire la città tra descrizioni e omissioni. Catania, 12-14 settembre 2013. Catania: Scrimm Edizioni, 2014. 
PARPAGLIOLO, Luigi. Codice delle antichità e degli oggetti d'arte: raccolta di leggi, decreti, regolamenti, circolari relativi alla conservazione delle cose d'interesse storico-artistico e alla difesa delle bellezze naturali. v. 1., 2. ed. Roma: La Libreria dello Stato, stampa 1932.

PERES, Fernando da Rocha. Memória da Sé. Salvador: Secretaria da Cultura e Turismo do Estado, 1999. Edição fac-símile de: Memória da Sé. Salvador: Macunaíma, 1974.

PINHEIRO, Maria Lucia Bressan. Neocolonial, modernismo e preservação do patrimônio no debate cultural dos anos 1920 no Brasil. São Paulo: Edusp; Fapesp, 2011.

PINHO, José Wanderley de Araújo. Protecção dos monumentos publicos e objectos historicos. Revista do Instituto Geográfico e Histórico da Babia, n. 43. Salvador: IGHB, 1917, p. 191-198.

PINHO, José Wanderley de Araújo. A Igreja da Sé - em torno de sua demolição. Proposta do Dr. José Wanderley de Araújo Pinho em sessão de 22 de março de 1925 e parecer da comissão. Revista do Instituto Geográfico e Histórico da Bahia, n. 51. Salvador: IGHB, 1925, p. 81-91.

PINHO, José Wanderley de Araújo. Coletânea de textos históricos. Apresentação de Consuelo Pondé de Sena. Salvador: Artes Gráficas, 1990.

PINHO, Wanderley de Araújo. Mobiliário, vestuário, jóias e alfaias dos tempos coloniais. Notas para uma nomenclatura baseada em documentos coevos. Revista do Patrimônio Histórico e Artístico Nacional, Rio de Janeiro, n. 4, p. 251-269, 1940.

PINHO, José Wanderley de Araújo. Anexo IV: Projeto do Deputado José Wanderley de Araújo Pinho. In: IPHAN. Proteção e revitalização do patrimônio cultural no Brasil: uma trajetória. Brasília: Sphan/Pró-Memória, 1980, p. 46-53.

RUBINO, Silvana. As fachadas da história: os antecedentes, a criação e os trabalhos do Serviço do Patrimônio Histórico e Artístico Nacional, 1937-1968. 1991. 206 f. Dissertação (Mestrado em Antropologia) - Instituto de Filosofia e Ciências Humanas, Universidade de Campinas. Campinas, 1991.

SANT'ANNA, Marcia. Da cidade-monumento à cidade-documento: a trajetória da norma de preservação de áreas urbanas no Brasil (1937-1990). 1995. Dissertação de Mestrado, Faculdade de Arquitetura e Urbanismo, Universidade Federal da Bahia - UFBA. Salvador, 1995.

SCHWARTZMAN, Simon; BOMENY, Helena Maria Bousquet; COSTA, Vanda Maria Ribeiro. Tempos de Capanema. São Paulo: Paz e Terra; Fundação Getulio Vargas, 2000. 
SENA, Consuelo Pondé de. O arquivo particular de Wanderley Pinho. Revista do Instituto Geográfico e Histórico da Babia, n. 90. Salvador: IGHB, 1992, p. 277-281.

SILVA, Aldo José Morais. Instituto Geográfico e Histórico da Babia. Origem e estratégias de consolidação institucional, 1894-1930. 2006. Tese (Doutorado) - Programa de PósGraduação em História da Universidade Federal da Bahia (UFBA). Salvador, 2006.

SILVA, Paulo Santos. Âncoras da Tradição: luta política, intelectuais e construção do discurso histórico da Bahia (1930-1940). Salvador: EDUFBA, 2000.

SOEIRO, Renato. Introdução. Revista do Patrimônio Histórico e Artístico Nacional, Rio de Janeiro, n. 17, p. 9-10, 1969.

VIANA FILHO, Luiz. Centenário de Wanderley Pinho. Revista do Instituto Geográfico e Histórico da Babia, n. 89. Salvador: IGHB, 1991, p. 17-24.

Artigo apresentado em 21/01/2019. Aprovado em 14/08/2019.

\section{(cc) BY}

All the contents of this journal, except where otherwise noted, is licensed under a Creative Commons Attribution License 